\title{
Asthenosphere-induced melting of diverse source regions for East Carpathian post-collisional volcanism
}

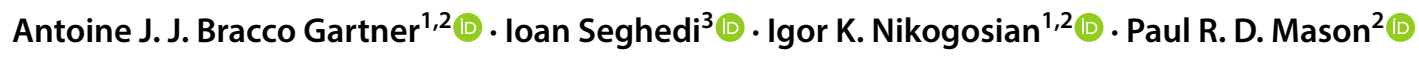

Received: 10 October 2019 / Accepted: 18 April 2020 / Published online: 7 May 2020

(c) The Author(s) 2020

\begin{abstract}
The occurrence of post-subduction magmatism in continental collision zones is a ubiquitous feature of plate tectonics, but its relation with geodynamic processes remains enigmatic. The nature of mantle sources in these settings, and their interaction with subduction-related components, are difficult to constrain using bulk rocks when magmas are subject to mixing and assimilation within the crust. Here we examine post-collisional magma sources in space and time through the chemistry of olivine-hosted melt inclusions and early-formed minerals (spinel, olivine and clinopyroxene) in primitive volcanic rocks from the Neogene-Quaternary East Carpathian volcanic range in Călimani (calc-alkaline; 10.1-6.7 Ma), Southern Harghita (calc-alkaline to shoshonitic; 5.3-0.03 Ma) and the Perşani Mountains (alkali basaltic; 1.2-0.6 Ma). Călimani calc-alkaline parental magma compositions indicate a lithospheric mantle source metasomatised by $\sim 2 \%$ sediment-derived melts, and are best reproduced by $\sim 2-12 \%$ melting. Mafic K-alkaline melts in Southern Harghita originate from a melt- and fluidmetasomatised lithospheric mantle source containing amphibole ( \pm phlogopite), by $\sim 5 \%$ melting. Intraplate Na-alkaline basalts from Racoș (Perşani) reflect small-degree (1-2\%) asthenosphere-derived parental melts which experienced minor interaction with metasomatic components in the lithosphere. An important feature of the East Carpathian post-collisional volcanism is that the lithospheric source regions are located in the lower plate (distal Europe-Moesia), rather than the overriding plate (Tisza-Dacia). The volcanism appears to have been caused by (1) asthenospheric uprise following slab sinking and possibly south-eastward propagating delamination and breakoff, which induced melting of the subduction-modified lithospheric mantle (Călimani to Southern Harghita); and (2) decompression melting as a consequence of minor asthenospheric upwelling (Perșani).
\end{abstract}

Keywords East Carpathians · Post-collisional magmatism · Subduction-modified mantle sources $\cdot$ Olivine-hosted melt inclusions $\cdot$ Spinel inclusions $\cdot$ Clinopyroxene

\section{Introduction}

Communicated by Timothy L. Grove.

Electronic supplementary material The online version of this article (https://doi.org/10.1007/s00410-020-01690-4) contains supplementary material, which is available to authorized users.

Antoine J. J. Bracco Gartner

a.j.j.braccogartner@vu.nl

1 Faculty of Science, Vrije Universiteit Amsterdam, De Boelelaan 1085, 1081 HV Amsterdam, The Netherlands

2 Department of Earth Sciences, Utrecht University, Princetonlaan 8a, 3584 CB Utrecht, The Netherlands

3 Institute of Geodynamics "Sabba S. Stefanescu", Romanian Academy, 19-21, Jean-Louis Calderon Str., 020032 Bucharest, Romania
A striking feature of plate tectonics is the occurrence of volcanism near continental plate boundaries after collision. Such post-collisional volcanic activity is often ascribed to thermal perturbation or decompression as a consequence of asthenospheric upwelling following slab breakoff (von Blanckenburg and Davies 1995), delamination (Bird 1979) or slab tearing (e.g. Rosenbaum et al. 2008). Perhaps as diverse as the proposed mechanisms for melt generation are the source regions from which primary melts originate in these settings. Sources include the lithospheric mantle, whose composition is typically modified by subduction, as well as the shallow asthenosphere. But whilst post-collisional volcanism cryptically reflects the physical process by which it was induced and, to some extent, the regional 
tectonic history prior to collision, their relation is complex and often difficult to decipher.

A relatively recent occurrence of post-collisional volcanism is found in the Neogene-Quaternary East Carpathian volcanic range (Fig. 1), where it postdates the westward subduction of a small ocean basin beneath the Tisza-Dacia microplate. Calc-alkaline magmatism ensued in a $160-\mathrm{km}$ long volcanic chain, termed Călimani-Gurghiu-Harghita (CGH), with minor eruptions of alkaline and potassium-rich magmas at the southern end (Perșani and Southern Harghita, respectively; Rădulescu and Săndulescu 1973; Seghedi and Downes 2011). Magmatic activity gradually shifted from northwest $(\sim 10 \mathrm{Ma})$ to southeast $(<0.03 \mathrm{Ma})$ with waning intensity (Peltz et al. 1987; Pécskay et al. 1995, 2006; Szakács et al. 1997, 2018), and has been linked to progressive along-strike slab breakoff (Mason et al. 1998; Seghedi et al. 1998) and/or lithospheric removal (e.g. Gîrbacea and Frisch 1998; Houseman and Gemmer 2007).

Gaining access to the source regions of primitive postcollisional magmas in general, and particularly in the East Carpathians and wider Carpathian-Pannonian region (Seghedi et al. 2004a), has proven to be challenging. Bulk rocks of the East Carpathian volcanic range represent averages of partial melts that have been modified significantly by magma mixing and assimilation within the crust (Mason et al. 1996, 1998). Such processes conceal the true nature and interaction of mantle and subduction components in the source. In contrast, melt inclusions (MIs) in forsteritic olivine are shielded from such modification after entrapment, and therefore provide more direct snapshots of primitive magma compositions. Hence, they allow more detailed constraints to be placed on the composition, heterogeneity and

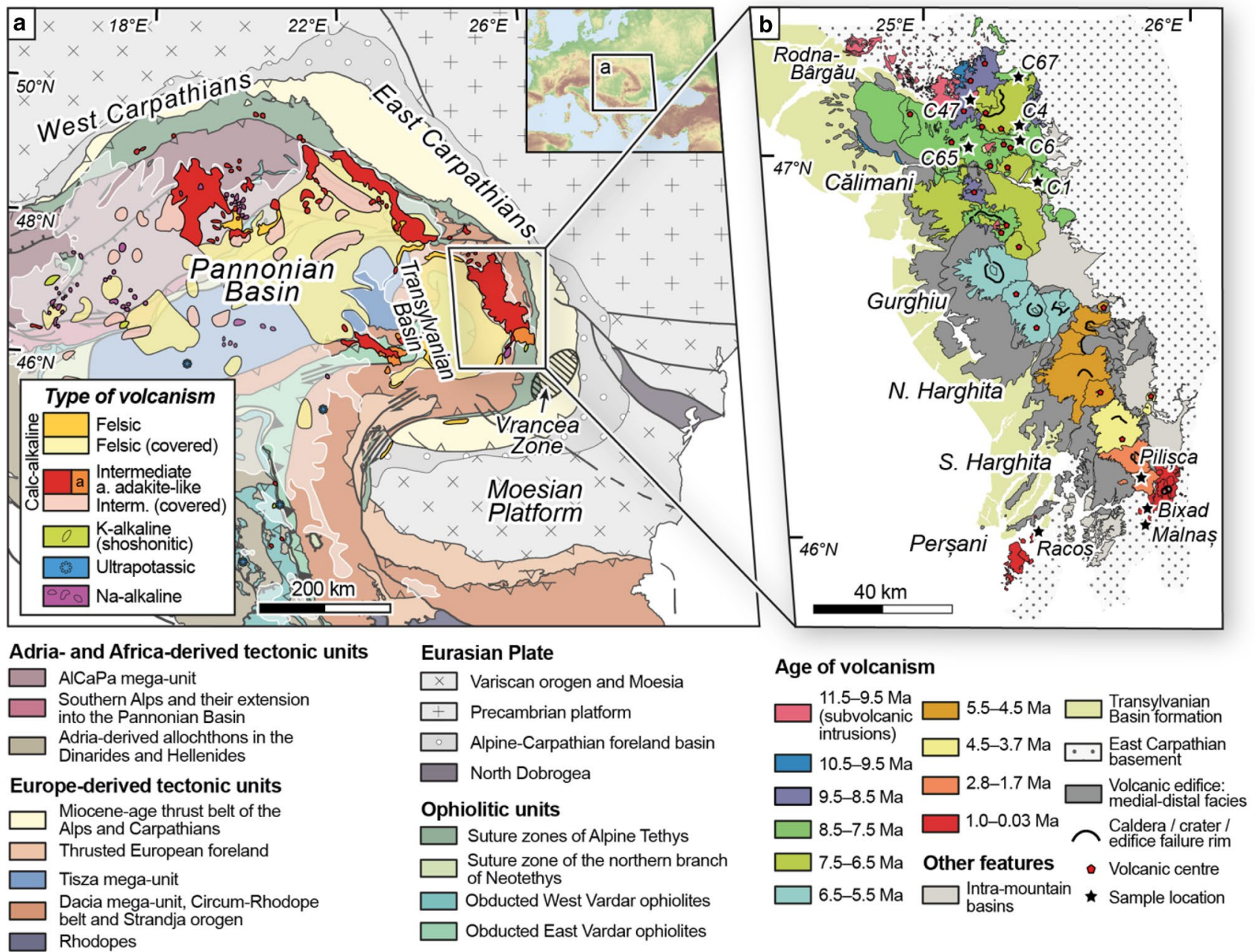

Fig. 1 a Tectonic map of the Carpathian-Pannonian region (Schmid et al. 2020) with the Miocene-Quaternary sedimentary cover (translucent white; simplified after Horváth et al. 2006) and magmatic centres (Pécskay et al. 2006; Seghedi and Downes 2011). Inset (top right) shows the location of a in Europe (topography from GTOPO30;
Gesch et al. 1999). b Simplified map of the East Carpathian volcanic range, showing the sample locations and the temporal and spatial evolution of volcanism (Seghedi et al. 2019; age data after Pécskay et al. 1995, 2006; Molnár et al. 2019) 
location of the mantle source (e.g. Sobolev 1996; Danyushevsky et al. 2002; Nikogosian et al. 2016, 2018).

Here we characterise the nature of East Carpathian postcollisional magmatism in Călimani, Southern Harghita (Pilișca, Bixad and Malnaș) and Perșani (Racoș) through the geochemistry of olivine-hosted melt inclusions and early liquidus minerals (spinel, olivine and clinopyroxene) in the most primitive rock samples. The aims of this study are to (1) determine the compositional characteristics of primary melts from Neogene-Quaternary post-collisional magmatism in the East Carpathians; (2) quantify source enrichment and mantle melting processes; (3) examine the temporal and spatial change in mantle source components; and (4) place magma genesis in a regional geodynamic framework.

\section{Geodynamic and magmatic setting}

The tectonic architecture of the Carpathian-Pannonian region, in eastern Central Europe (Fig. 1a), is the result of the movement and collision of the European and Adriatic continental plates and interposed continental blocks ( $\mathrm{AlCaPa}$, Tisza, Dacia) during the Alpine orogeny in Cretaceous to Neogene times (e.g. Royden 1988; Săndulescu 1988; Csontos 1995). During the Oligocene-Miocene, the $\mathrm{AlCaPa}$ and Tisza-Dacia blocks were emplaced into the Carpathian embayment as the westward subduction zone of European lithosphere retreated (Balla 1987; Ustaszewski et al. 2008). This E-W convergence led to the development of large foreland fold and thrust belts, molasse basins and flysch deposits at the eastern margins of $\mathrm{AlCaPa}$ and Tisza-Dacia (Fig. 1a), and culminated in continental collision around 10-12 Ma (Matenco and Bertotti 2000; Gagała et al. 2012).

The Miocene subduction of presumed oceanic European lithosphere beneath the $\mathrm{AlCaPa}$ and Tisza-Dacia blocks resulted in large volumes of subduction-related magmatism in the East Carpathians during Middle Miocene to Pleistocene times (e.g. Lexa et al. 2010; Seghedi and Downes 2011). In the north, this activity gave rise to an assortment of volcanic fields on the eastern edge of AlCaPa (Fig. 1a), mainly between 14 and $9 \mathrm{Ma}$ (Pécskay et al. 2006; Kovacs et al. 2017), and a sub-volcanic zone at 11.5-8 Ma around its south-eastern border with Tisza-Dacia (Pécskay et al. 2009; Fedele et al. 2016). Progressing south-eastward on TiszaDacia, it produced the $160-\mathrm{km}$ long CGH volcanic chain (Fig. 1b) between 10.1 and <0.03 Ma (Pécskay et al. 2006). Magmatic activity postdates Middle Miocene subduction (Cloetingh et al. 2004) and is thus considered to be postcollisional (Mason et al. 1998; Seghedi et al. 1998, 2019; Seghedi and Downes 2011). CGH magmatism is characterised by a clear south-eastward decrease in age and intensity (Peltz et al. 1987; Pécskay et al. 1995, 2006; Szakács et al.
1997, 2018) and produced adjoining composite volcanoes and peripheral volcaniclastic aprons (Szakács and Seghedi 1995), with products ranging from basalts to rhyolites (Seghedi et al. 1995; Mason et al. 1996).

Magmatism in the northernmost complex of the CGH chain, the Călimani Mountains (Fig. 1b), occurred from 10.1 to $6.7 \mathrm{Ma}$ (Pécskay et al. 1995, 2006). Volcanic products in this area, and similarly in the Gurghiu and Northern Harghita Mountains (9.0-3.9 Ma; Pécskay et al. 1995, 2006), are mainly calc-alkaline rocks with andesitic and dacitic compositions. Trace-element and isotope compositions indicate extensive crustal contamination and suggest an imprint of subducted sediments in the mantle source (Mason et al. 1996). On the whole, calc-alkaline products of the CGH chain suggest derivation from a fairly homogeneous subduction-related mantle source (Mason et al. 1996).

Magmatic activity in Southern Harghita (Fig. 1b) is marked by a shift to adakite-like, (high-K) calc-alkaline and shoshonitic compositions starting at 5.3 Ma (Szakács et al. 1993, 2015; Pécskay et al. 1995; Seghedi et al. 1995, 2004a; Molnár et al. 2018). Major edifices in this area (Pilișca, Ciomadul, Luci-Lazu and $\mathrm{Cucu}$ ) are (high-K) calc-alkaline, andesitic to dacitic in composition, yet two smaller, isolated domes of shoshonitic ("K-alkaline") trachyandesitic composition occur at Bixad and Malnaș (Fig. 1b). Southern Harghita is situated $\sim 50 \mathrm{~km} \mathrm{NW}$ of the Vrancea Zone (Fig. 1a), where a near-vertical slab is imaged in the upper mantle (Martin and Wenzel 2006; Ismail-Zadeh et al. 2012; Popa et al. 2012). The active seismicity in this area has been argued to represent the terminal stage of subduction with ongoing slab detachment (Wortel and Spakman 2000; Sperner et al. 2001; Martin and Wenzel 2006), lithospheric delamination beneath an overthickened collision zone (Knapp et al. 2005; Koulakov et al. 2010; Fillerup et al. 2010), or a combination of subduction rollback and lithospheric delamination (Gîrbacea and Frisch 1998; ChalotPrat and Girbacea 2000). Changes in magma composition in this area have been attributed to slab pull and steepening alongside opening of a slab tear window, as well as tectonic inversion associated with deep-mantle processes (Seghedi et al. 2011).

Contemporaneous intraplate, Na-alkaline basaltic magmatism developed $35 \mathrm{~km}$ westward in a monogenetic volcanic field located at the western margin of the Perșani Mountains (Fig. 1b), between the Transylvanian and Brașov Basins (Downes et al. 1995; Seghedi et al. 2011, 2016; Harangi et al. 2013). The volcanic centres (including Racoș, Mateiaș, Sărata, Bogata, Gruiu and Bârc) are arranged parallel to a NNE-SSW-trending normal fault system (Gîrbacea et al. 1998; Ciulavu et al. 2000) and developed in six eruptive episodes between 1.2 and $0.6 \mathrm{Ma}$ (Panaiotu et al. 2013; Seghedi et al. 2016). Products are alkaline trachybasaltic in composition, and are considered to be derived 
from an asthenospheric source (Downes et al. 1995; Seghedi et al. 2004b, 2011). Perșani magmas appear to have a minor subduction-related component in their source, or may have interacted with subduction-modified lithosphere during ascent (Embey-Isztin et al. 1993; Downes et al. 1995; Embey-Isztin and Dobosi 1995; Seghedi et al. 2004b). Tomographic evidence for a low-velocity anomaly and highattenuation volume beneath the area (Russo et al. 2005; Popa et al. 2005; Martin and Wenzel 2006; Popa et al. 2012) has been linked to asthenospheric upwelling and magma generation (Seghedi et al. 2011).

\section{Studied samples}

The whole-rock samples from Călimani, Southern Harghita (Pilișca, Bixad and Malnaș) and Perșani (Racoș) selected for this study cover the compositional variability present in primitive products of the East Carpathian volcanic range. The petrography and whole-rock geochemistry of these samples has previously been documented (Downes et al. 1995; Mason et al. 1995, 1996; Seghedi et al. 1995). Their compositions are listed in Online Resource Table A1.

Călimani samples represent the most primitive products (i.e. highest $\mathrm{MgO}$ and lowest $\mathrm{SiO}_{2}$ content) of this volcanic centre. Călimani sample C1 (8.5-8.3 Ma) was taken from the isolated shield volcano also known as the Sărmaş basalt; C4 and C6 (9.8-9.6 Ma) from the early Rusca-Tihu edifice volcanic rocks; C65 and C67 (8.9-8.6 Ma) from the late RuscaTihu edifice; and C47 (10.6 Ma) from the pre-volcanic intrusions (detailed map in Online Resource Fig. A1) (Pécskay et al. 1995; Seghedi et al. 2005). Samples C4, C47, C65 and C67 classify as basalts, $\mathrm{C} 1$ as a basaltic trachyandesite, and C6 as a basaltic andesite (Fig. 2a). They are calc-alkaline

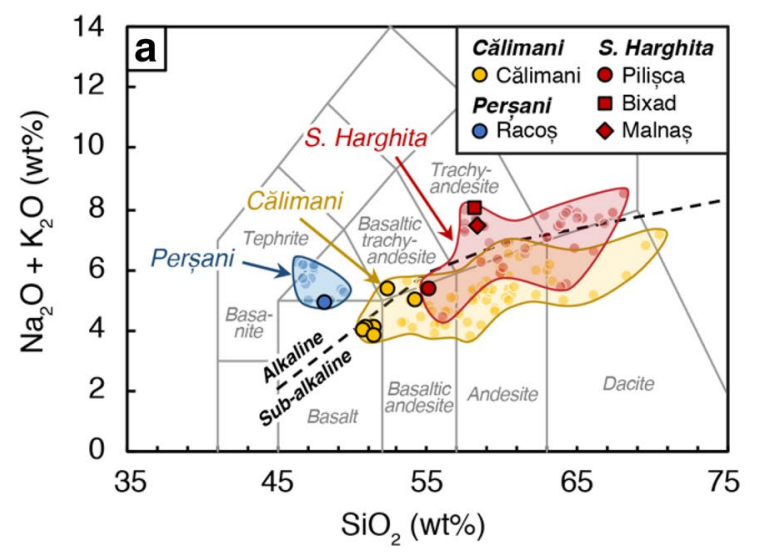

Fig. 2 Classification diagrams for the selected primitive rock samples from Călimani, Southern Harghita (Pilișca, Bixad and Malnaș; Mason 1995) and Perșani (Racoș; Downes et al. 1995). a $\mathrm{SiO}_{2}$ versus total alkali $\left(\mathrm{Na}_{2} \mathrm{O}+\mathrm{K}_{2} \mathrm{O}\right.$; wt\%) classification diagram (Le Bas et al. 1986). Boundary between alkaline and sub-alkaline fields after Miyashiro
(C4, C47, $\mathrm{C} 65$ and $\mathrm{C} 67)$ to high-K calc-alkaline ( $\mathrm{C} 1$ and $\mathrm{C6}$ ) in character, and effectively cover the range in $\mathrm{K}_{2} \mathrm{O}$ content $(\sim 0.5-2 \mathrm{wt} \%)$ present in the least-evolved Călimani products (Fig. 2b). C47 represents a rare, primitive sample of the low-K group of sub-volcanic intrusions documented in the Bârgău area (Fedele et al. 2016), which is located directly north of Călimani (Fig. 1b).

Samples from Southern Harghita were taken from the volcanic complex of Pilișca (sample H11; 1640 $\pm 37 \mathrm{ka}$ ) and the quarries of Bixad (also referred to as "Bicsad" or "Murgul Mic"; sample H3; $907 \pm 66 \mathrm{ka}$ ) and Malnaș (sample H52; 964 \pm 46 ka) (ages from Molnár et al. 2018). Basaltic andesite $\mathrm{H} 11$ is calc-alkaline, and trachyandesites $\mathrm{H} 3$ and H52 classify as shoshonites, thereby spanning the wide range in $\mathrm{K}_{2} \mathrm{O}$ content (1-4 wt\%) observed in Southern Harghita volcanics (Fig. 2b) (Mason et al. 1996; Molnár et al. 2018).

Perșani samples were taken from the Racoș lava flow (sample "Racos"; 1221 11 ka) (Downes et al. 1995; age from Panaiotu et al. 2013). Collectively, Perșani lavas classify as alkaline and mainly trachybasaltic, and show relatively limited compositional variability (Fig. 2a).

\section{Methods}

Rock samples were crushed and sieved, after which olivine and clinopyroxene phenocrysts were handpicked using a binocular microscope. These were mounted in epoxy and polished on one side to determine major elements by electron microprobe analysis (EPMA). Forsterite-rich olivine grains containing MIs were selected and polished until the MIs were within a few $\mu \mathrm{m}$ of being exposed, for trace-element analysis by laser ablation inductively coupled plasma

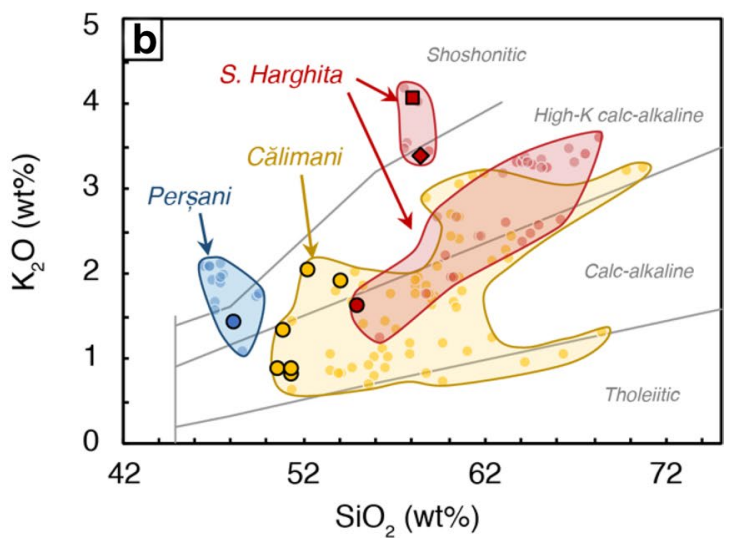

(1978). b $\mathrm{SiO}_{2}$ versus $\mathrm{K}_{2} \mathrm{O}$ (wt\%) classification diagram (Peccerillo and Taylor 1976). Concentrations were normalised to $100 \mathrm{wt} \%$ on a volatile-free basis. Published whole-rock data are from Downes et al. (1995), Mason (1995), Harangi et al. (2013) and Molnár et al. (2018) 
mass spectrometry (LA-ICP-MS). The MIs were present predominantly as isolated inclusions, occasionally in small clusters, oriented along growth zones of the olivine host, characteristic of inclusions of primary origin (e.g. Roedder 1984). They were all partially or fully crystallised, typically sub-spherical in shape with diameters ranging from $\sim 20$ to $40 \mu \mathrm{m}$.

Major element data on olivine, spinel and clinopyroxene were obtained using a JEOL JXA-8600 SuperProbe at Utrecht University, following the procedure outlined in De Hoog et al. (2001). Analyses were performed in wavelength dispersive mode, using an accelerating voltage of $15 \mathrm{kV}$ and a beam current of $10 \mathrm{nA}$. Natural minerals, metals and synthetic oxides were used as calibration standards. Monitoring of San Carlos olivine (USNM 111312/44) indicated accuracy within 5\% (Jarosewich et al. 1980) for all reported oxides.

Trace elements in MIs and clinopyroxene were determined using a 193-nm GeoLas 200Q Excimer laser ablation system, coupled to a Micromass Platform quadrupole ICP-MS instrument at Utrecht University, following procedures described in Mason et al. (2008). The laser
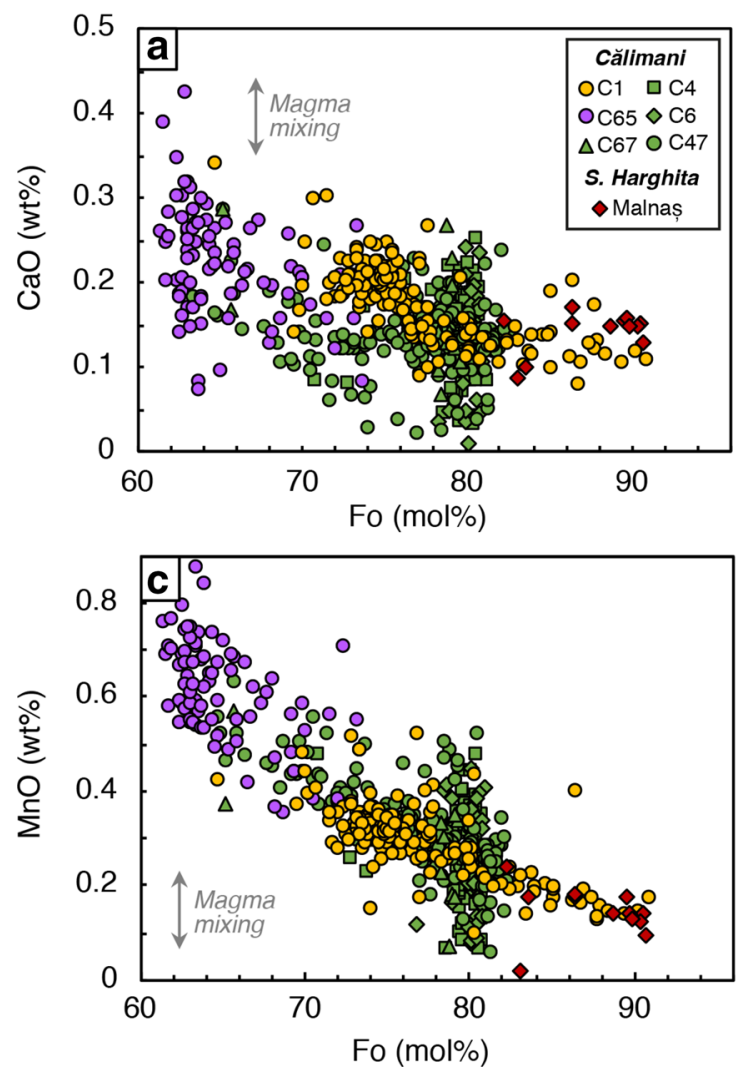

Fig. 3 Major-oxide compositions of the olivine phenocrysts from Călimani, Southern Harghita and Perșani. Forsterite (Fo; mol\%) versus $\mathrm{CaO}$ (a and b) and $\mathrm{MnO}$ content (wt\%; c and d) at Călimani, Malnaș (Southern Harghita) and Perșani (including was operated at a repetition rate of $10 \mathrm{~Hz}$ and fluence of $10-15 \mathrm{~J} / \mathrm{cm}^{2}$ with a $40-\mu \mathrm{m}$ spot diameter. Samples were ablated for 25-30 s, with background count rates measured before and after. MIs were consumed in their entirety and homogenised during ablation. The time-resolved signals recorded during ablation were carefully checked for compositional boundaries and constancy to ensure that only data on uncompromised MIs were integrated. Contribution of the host olivine was gauged by its signal prior to MI ablation, and was subtracted from the mixed signal (Halter et al. 2002). Quantitative concentrations were calculated using NIST SRM 612 as a calibration standard (Pearce et al. 1997), using Ca either as measured by EPMA (for clinopyroxene analyses) or in the respective whole-rock samples (for MI analyses) as an internal standard. USGS reference glass BCR-2G was used as a secondary standard throughout analysis and indicated accuracy within $10 \%$ of the GeoReM preferred values (Jochum and Stoll 2008) for all trace elements.

The limited variability in whole-rock $\mathrm{Ca}$ content (Downes et al. 1995; Mason et al. 1996) and overall similarities between respective whole-rock and MI trace-element
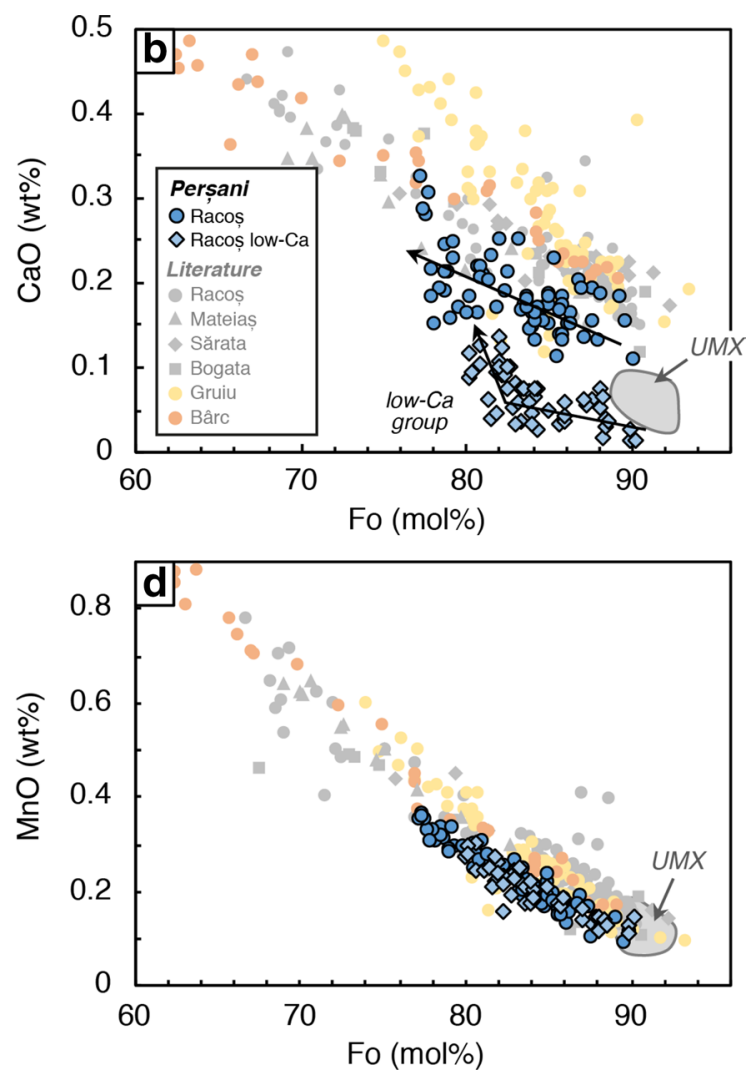

Racoș). UMX = olivines from ultramafic Perșani xenoliths (Vaselli et al. 1995; Falus et al. 2008). Published Perșani data (from Racoș, Mateiaș, Sărata, Bogata, Gruiu and Bârc) are from Vaselli et al. (1995) and Harangi et al. (2013) 
distributions (Fig. 6) indicate that the whole-rock $\mathrm{Ca}$ concentrations provide a realistic estimate of the Ca budget of the MIs. Nonetheless, possible variability in the Ca contents of the MIs (if used as the normalising element for LA-ICPMS) would induce a minor, uniform shift to the absolute abundances of their trace elements. To ensure independence from such potential variations, the discussion below is focused on ratios of trace elements in MIs, rather than absolute concentrations.

\section{Results}

\section{Mineral chemistry}

\section{Olivine phenocrysts}

Compositions of the olivine phenocrysts $(\mathrm{Fo}=\mathrm{Mg} /(\mathrm{Mg}+\mathrm{Fe})$ in $\mathrm{mol} \%$ ) in the selected rock samples (Online Resource Table A2) vary from $\mathrm{Fo}_{91}$ to $\mathrm{Fo}_{58}$ in Călimani $(n=674)$, $\mathrm{Fo}_{91}$ to $\mathrm{Fo}_{82}$ in Southern Harghita $(n=12)$, and $\mathrm{Fo}_{90}$ to $\mathrm{Fo}_{78}$ in Racoș (Perșani; $n=123$; Fig. 3). On the whole, Fo
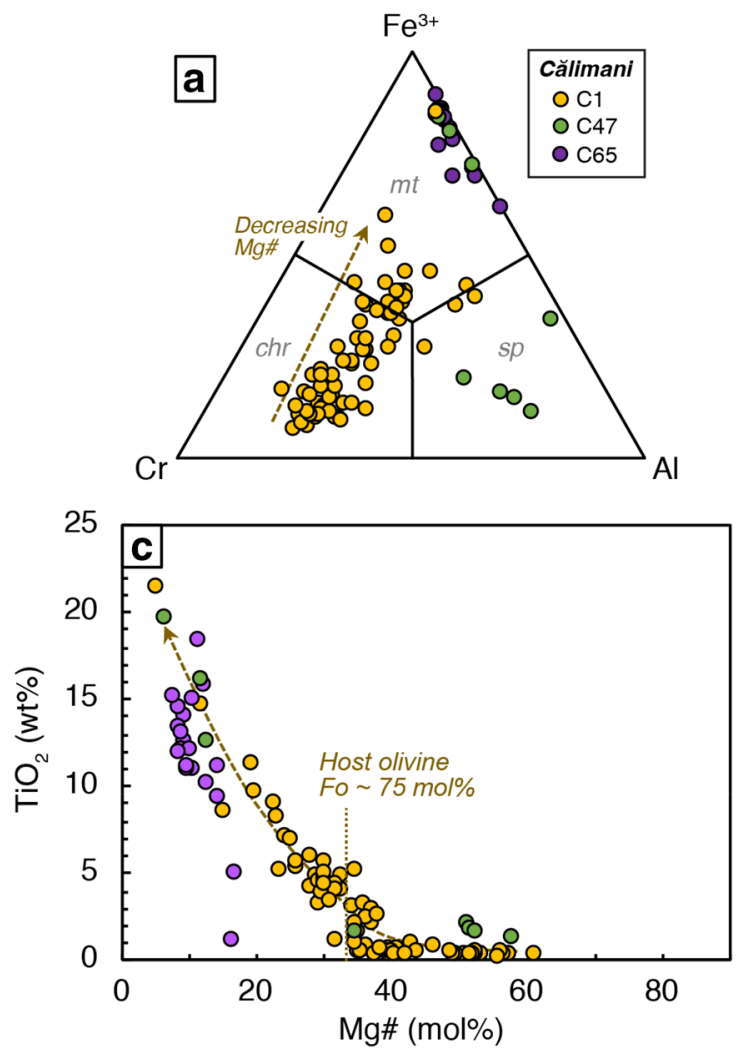

Fig. 4 Compositional features of spinel inclusions in olivines from Călimani and Perșani. Cr-Al-Fe ${ }^{3+}$ ternary diagram (Stevens 1944) for spinels from a Călimani and b Perșani (Racoș and other localities). $\mathrm{Sp}=$ spinel; $\mathrm{chr}=$ chromite; $\mathrm{mt}=$ magnetite. $\mathrm{Mg} \#(\mathrm{Mg} /$ $\left(\mathrm{Mg}+\mathrm{Fe}^{2+}\right)$ in mol\%) versus $\mathrm{TiO}_{2}$ content (wt\%) in c Călimani and $\mathbf{d}$ content correlates with minor constituents such as $\mathrm{NiO}$, and inversely with $\mathrm{CaO}$ and $\mathrm{MnO}$, in line with typical fractionation processes. Nonetheless, Fig. 3 illustrates considerable variability in e.g. $\mathrm{CaO}$ and $\mathrm{MnO}$ content at narrow Fo intervals, such as that centred around $\mathrm{Fo}_{80}$ and $\mathrm{Fo}_{64}$ in Călimani, and between $\mathrm{Fo}_{90}$ and $\mathrm{Fo}_{78}$ in Racoș.

Multiple fractionation trends are observed in the $\mathrm{CaO}$ content of Racoş olivines (Fig. 3b). The trend which comprises the highest-Ca olivines plots parallel to the trends reported by Harangi et al. (2013) for collective Perșani olivines (with the exception of Gruiu). The lowest-Ca, highest-Fo olivines plot close to olivine megacrysts (Harangi et al. 2013) and olivines from ultramafic xenoliths found in the Perșani basalts (Vaselli et al. 1995; Falus et al. 2008), but form part of a continuous low-Ca fractionation trend not documented before (see also Online Resource Fig. A2).

\section{Spinel inclusions in olivine}

Spinel inclusions were identified in olivines from Călimani and Racoș (Online Resource Table A3; with $\mathrm{Fe}^{2+}$ and $\mathrm{Fe}^{3+}$ calculated assuming stoichiometry). Spinel hosted by more
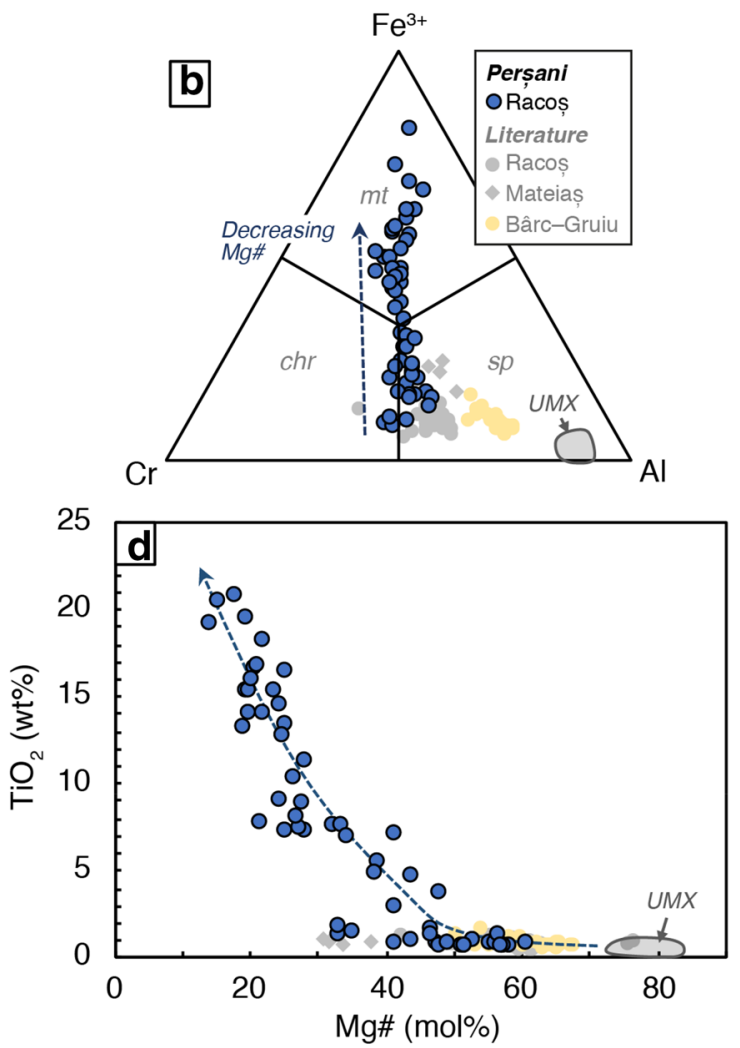

Perşani spinels. $\mathrm{Fe}^{2+}$ and $\mathrm{Fe}^{3+}$ were calculated on the basis of stoichiometry. UMX = spinels in olivines from ultramafic Perșani xenoliths (Vaselli et al. 1995; Falus et al. 2008). Additional Perșani spinel data (from Racoș, Mateiaş and Bârc-Gruiu) are from Harangi et al. (2013) 
evolved olivines are enriched in $\mathrm{TiO}_{2}(>2 \mathrm{wt} \%)$ and total $\mathrm{FeO}(>40 \mathrm{wt} \%$ ), and approach Ti-magnetite compositions (Fig. 4). In Călimani, the Fo content of the host olivines tends to correlate positively with $\mathrm{Mg} \#\left(\mathrm{Mg} /\left(\mathrm{Mg}+\mathrm{Fe}^{2+}\right)\right.$ in mol\%) and $\mathrm{Fe}^{2+} / \mathrm{Fe}^{3+}$, and negatively with the $\mathrm{Fe}^{3+}$ and $\mathrm{TiO}_{2}$ content, of the enclosed spinels (Fig. 4c). For Racos, the same holds true for $\mathrm{Mg \#}, \mathrm{Fe}^{3+}$ and $\mathrm{TiO}_{2}$ content (Fig. 4d); trends in $\mathrm{Fe}^{2+} / \mathrm{Fe}^{3+}$ are less apparent over the narrow Fo interval.

In Călimani $\mathrm{C} 1$, most spinel inclusions hosted by olivines with $\mathrm{Fo}>78 \mathrm{~mol} \%$ are chromian $(\mathrm{Cr}-)$ spinel $\left(\mathrm{Cr}_{2} \mathrm{O}_{3}=36-56\right.$ wt $\%, \mathrm{Al}_{2} \mathrm{O}_{3}=10-18$ wt $\%$ ) with $\mathrm{TiO}_{2}$ content ranging from 0.2 to $1.0 \mathrm{wt} \%$, i.e. characteristic of magmatic spinels (Kamenetsky et al. 2001). The Cr\# of C1 Cr-spinels (56-83 mol\%) are notably higher than those from sample C47 (3-35 mol\%), which contain less $\mathrm{Cr}_{2} \mathrm{O}_{3}(16-23 \mathrm{wt} \%)$ and more $\mathrm{Al}_{2} \mathrm{O}_{3}(28-39 \mathrm{wt} \%)$ at similar host-olivine Fo content. Sample C65, consistent with the more evolved nature of the olivine hosts, contains spinel with generally high $\mathrm{TiO}_{2}$ content (9-18 wt\%) and low $\mathrm{Cr} \#(1-23 \mathrm{~mol} \%)$ and $\mathrm{Cr}_{2} \mathrm{O}_{3}$ content $(0.2-1.0 \mathrm{wt} \%)$.
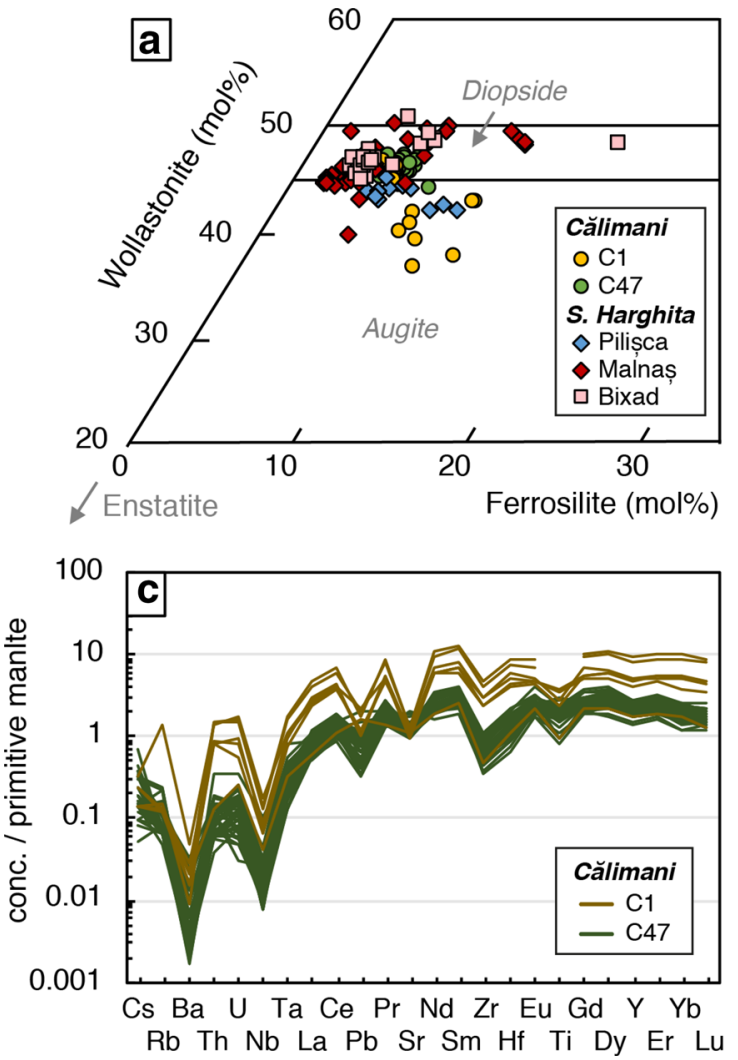

Fig. 5 Compositions of clinopyroxene phenocrysts from Călimani and Southern Harghita. a Inset of wollastonite-enstatite-ferrosilite classification diagram (boundaries after Morimoto 1988), with endmember components calculated following Cawthorn and Collerson
Racoș spinel inclusions with $\mathrm{Mg \#}>33 \mathrm{~mol} \%$ are predominantly $\mathrm{Cr}$-spinel $\left(\mathrm{Cr}_{2} \mathrm{O}_{3}=24-39 \mathrm{wt} \%, \mathrm{Al}_{2} \mathrm{O}_{3}=17-27 \mathrm{wt} \%\right)$, with $\mathrm{TiO}_{2}$ content ranging from 0.7 to $1.8 \mathrm{wt} \%$ (Fig. $4 \mathrm{~d}$ ). The $\mathrm{Cr} \#$ of Racos spinels (42-54 mol\%) is relatively uniform and similar to, yet slightly broadens the range of, those reported for Racoș-Hegheș and Mateiaș (36-49; average = $42 \mathrm{~mol} \%$ ), and markedly higher than those of Bârc and Gruiu (24-34; average $=27 \mathrm{~mol} \%$; Harangi et al. 2013).

\section{Clinopyroxene phenocrysts}

Clinopyroxene phenocrysts from Călimani and Southern Harghita (Pilișca, Bixad and Malnaș; Online Resource Table A4) are predominantly diopside to $\mathrm{Mg}$-rich augite (Fig. 5a). Mg\# varies substantially within the different samples (Fig. 5b), with markedly higher values at Bixad (85-92 mol\%) and Malnaș (86-92, down to $70 \mathrm{~mol} \%$ ), than in Călimani (C1: 73-86; C47: 82-89 mol\%) and Pilișca (76-86 mol\%). In line with typical fractionation trends, sev-

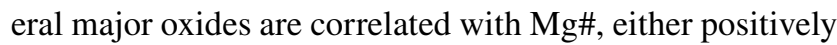
$\left(\mathrm{SiO}_{2}\right.$ and $\left.\mathrm{Cr}_{2} \mathrm{O}_{3}\right)$ or negatively $\left(\mathrm{TiO}_{2}, \mathrm{Al}_{2} \mathrm{O}_{3}\right.$ and $\left.\mathrm{MnO}\right)$.
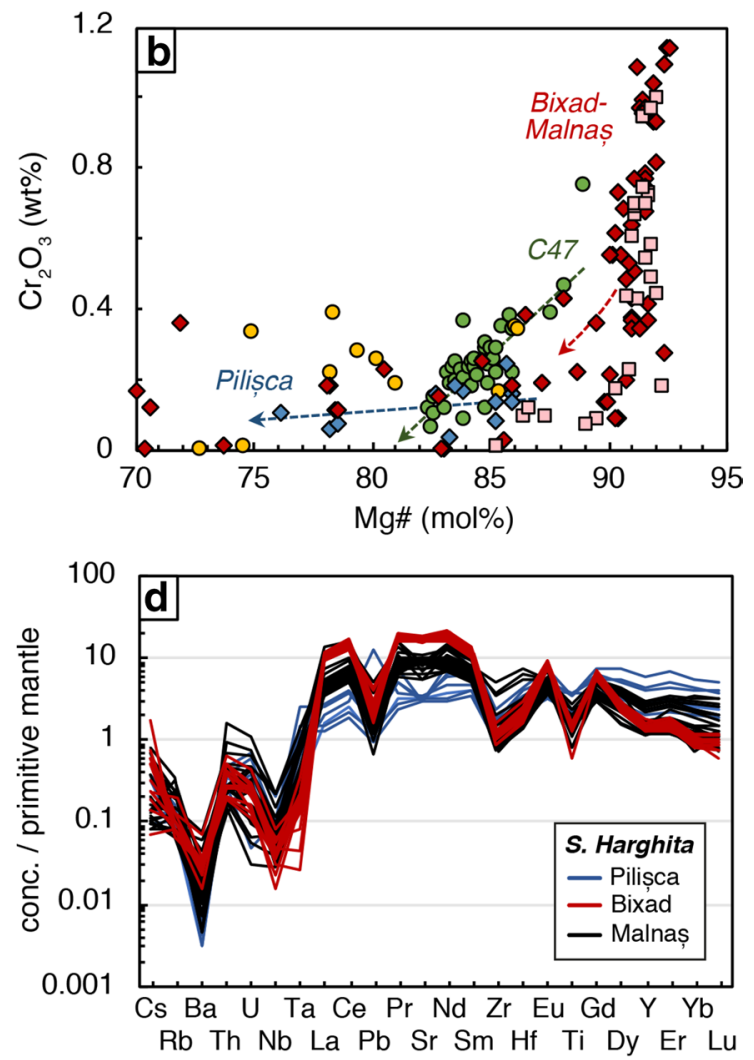

(1974). b $\mathrm{Mg} \#$ (mol\%) versus $\mathrm{Cr}_{2} \mathrm{O}_{3}$ (wt\%). Fractionation trends are shown as dashed lines with arrows. Primitive mantle-normalised (McDonough and Sun 1995) incompatible trace-element patterns for clinopyroxenes from c Călimani and d Southern Harghita 
Most notably, Bixad and Malnaş clinopyroxenes are distinguished from the others by highly variable, and higherreaching $\mathrm{Cr}_{2} \mathrm{O}_{3}$ (0.1-1.1 wt\%; Fig. 5b) and $\mathrm{Na}_{2} \mathrm{O}$ values (0.1-0.6 wt \%).

The contrast between clinopyroxenes from Bixad and Malnaș (shoshonitic) and Călimani and Pilișca (calc-alkaline) is further exemplified by their trace-element contents (Fig. 5c, d). Călimani and Pilișca clinopyroxenes exhibit modest ranges in trace-element abundances, such as $\mathrm{Sr}$ (19-40 and 60-71 ppm), La (0.3-3 and 1-3 ppm), and ratios such as light over heavy rare-earth elements (LREE/ HREE; La/Yb $=0.4-1$ and 1), middle over heavy rareearth elements (MREE/HREE; $\mathrm{Sm} / \mathrm{Yb}=1-2$ and 1.4-1.8) and $\mathrm{Sr} / \mathrm{Y}$ (1-7 and 2-7; Online Resource Fig. A3b). Conversely, Bixad and Malnaș clinopyroxenes are characterised by exceedingly high $\mathrm{Sr}$ (306-387 and 109-216 ppm) and La content (6-8 and 2-9 ppm), as well as $\mathrm{La} / \mathrm{Yb}(13-20$ and 2-9), $\mathrm{Sm} / \mathrm{Yb}(9-14$ and 2-8) and $\mathrm{Sr} / \mathrm{Y}$ ratios (38-62 and 8-40).
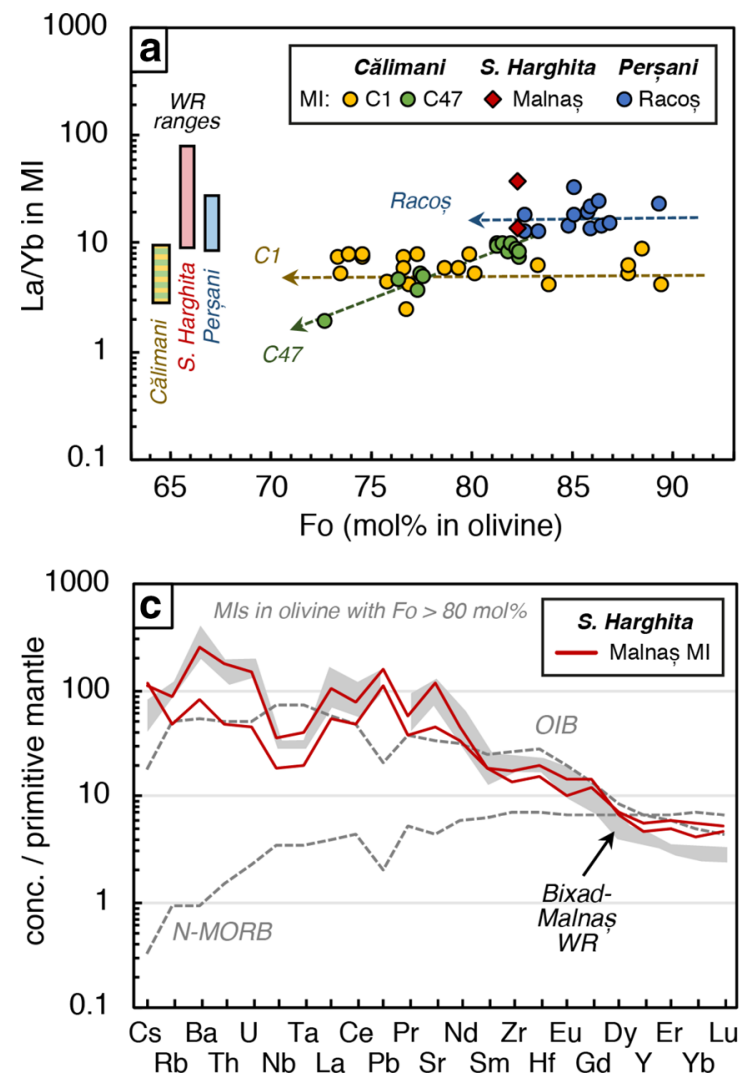

Fig. 6 Compositions of melt inclusions (MIs) in olivines from Călimani, Southern Harghita (Malnaş) and Perşani (Racoş). a Hostolivine forsterite content (Fo in $\mathrm{mol} \%$ ) versus $\mathrm{La} / \mathrm{Yb}$ in MI. Fractionation trends are shown as dashed lines with arrows. Primitive mantlenormalised (McDonough and Sun 1995) incompatible trace-element diagrams for MIs (in olivines with Fo $>80$ mol\%) from b Călimani,

\section{Melt inclusions in olivine}

Magmatic inclusions were identified in olivines from Călimani, Perșani (Racoș) and, despite the scarcity of olivine, also from Malnaș. Their trace-element data are listed in Online Resource Table A5. Figure 6 shows that Călimani MIs cover a compositional range that exceeds that of primitive whole-rock data. Whilst C1 MIs show a wide range of, but no systematic trend in LREE/HREE (e.g. La/Yb) with decreasing host-olivine Fo content (Fig. 6a), those of C47 exhibit a positive correlation between the two. On the whole, C47 exhibits minor compositional diversity, whereas C1 shows slightly wider ranges for many trace-element ratios (e.g. $\mathrm{La} / \mathrm{Sm}=3-6$ and $1-6 ; \mathrm{Ba} / \mathrm{La}=13-29$ and $1-29 ; \mathrm{Ce} /$ $\mathrm{Pb}=2-6$ and $0.5-5$, respectively). The primitive mantle (PM)-normalised incompatible trace-element patterns of $\mathrm{C} 1$ MIs (Fig. 6b) illustrate enrichments in large-ion lithophile elements over high-field-strength elements (LILE/HFSE; e.g. $\mathrm{Ba} / \mathrm{Nb}$ ), which are consistent with whole-rock trends (Mason et al. 1996). The patterns are marked by pronounced
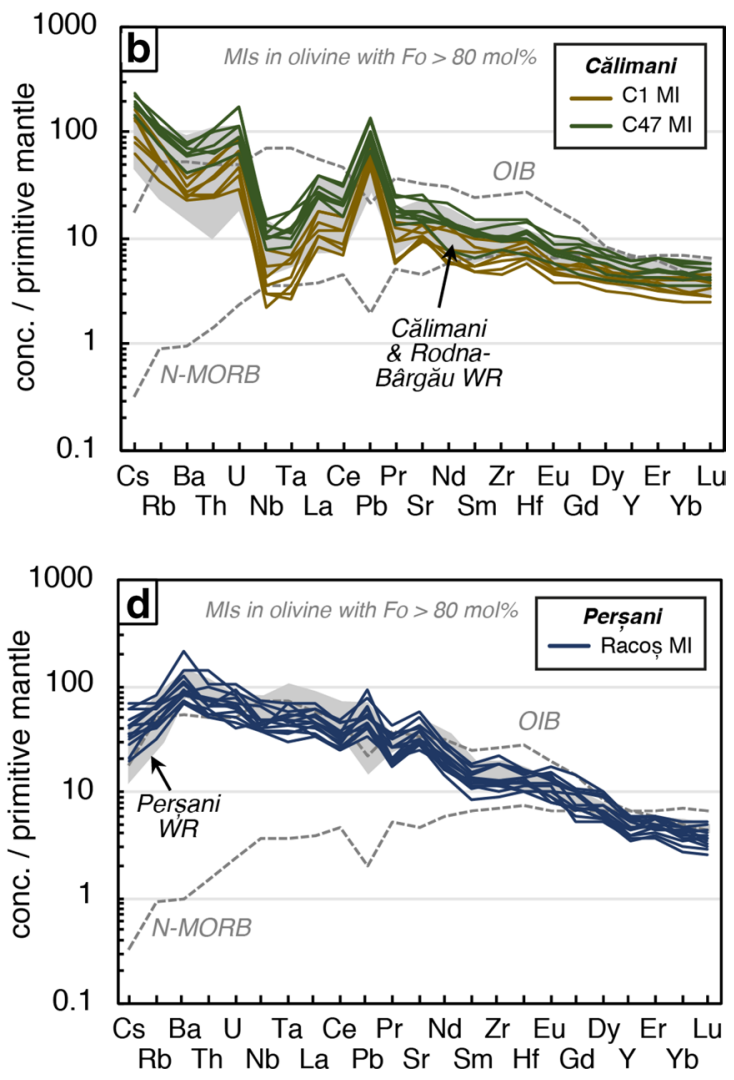

c Malnaș and d Racoș. Primitive whole-rock (WR; $\mathrm{MgO}>4 \mathrm{wt} \%$ and $\mathrm{SiO}_{2}<55-58$ wt\%; Downes et al. 1995; Mason 1995; Mason et al. 1998; Harangi et al. 2013; Fedele et al. 2016; Molnár et al. 2018), N-MORB and OIB (Sun and McDonough 1989) compositions are shown for comparison 
troughs at $\mathrm{Nb}-\mathrm{Ta}$ and positive $\mathrm{Pb}$ anomalies, both features typical for subduction-related magmas. Patterns for C47 are somewhat less variable and plot close to their host-rock pattern, except for slight relative enrichments in $\mathrm{Rb}, \mathrm{Ba}$ and Th. Whilst relative depletions in $\mathrm{Nb}$-Ta are of similar magnitude to $\mathrm{C} 1, \mathrm{C} 47 \mathrm{MIs}$ show less-pronounced $\mathrm{Pb}$ spikes and, overall, slightly elevated patterns.

Malnaş MIs are marked by significantly higher abundances of most trace elements compared to Călimani. They show greater LREE/HREE enrichments (La/Yb $=14-37$; Fig. 6c) and considerably higher Sr/Y ratios (38-118). Also evident is considerable MREE/HREE fractionation $(\mathrm{Sm} / \mathrm{Yb}=3-4)$ and trace-element patterns which, albeit with characteristic troughs at $\mathrm{Nb}-\mathrm{Ta}$ and small positive $\mathrm{Pb}$ anomalies, approach enrichment levels typically associated with ocean-island basalt (OIB)-type magmas.

Racos MIs cover a compositional spectrum wider than that of the whole rocks, approaching that of collective Perșani basalts. They exhibit high LREE/HREE ratios (La/ $\mathrm{Yb}=12-32$; Fig. 6d) and incompatible trace-element patterns which resemble those of OIBs, albeit variable and with somewhat higher LILE (Cs, Ba), $\mathrm{Pb}$ and lower HFSE ( $\mathrm{Nb}$, $\mathrm{Ta}, \mathrm{Zr}$ and Hf) and MREE content.

\section{Discussion}

\section{Early liquidus assemblages and fractional crystallisation}

Detailed information on early liquidus assemblages is a prerequisite for characterising parental melts and, by extension, the mantle source from which they originate. Călimani olivines exhibit considerable variability in minor-oxide compositions over narrow Fo intervals centred around $\mathrm{Fo}_{80}(\mathrm{C} 4$, C6, C67) and $\mathrm{Fo}_{64}$ (C65) (Fig. 3). Such features necessitate extensive mixing and back-mixing processes to have occurred during fractionation. This view is supported by the occurrence of low-Ca olivines at Fo $80 \mathrm{~mol} \%$ (samples C4, C6 and C67; Fig. 3a) not present at $>82 \mathrm{~mol} \%$, which could be of mixed-in, non-magmatic origin (e.g. Hirano et al. 2004; Nikogosian and van Bergen 2010). It is noteworthy that this occurrence is observed in samples from both early (9.8-9.6 Ma; C4 and C6) and later Rusca-Tihu rocks (8.9-8.6 Ma; C67), which testifies to a relatively continuous and well-established magmatic plumbing system during Călimani (Rusca-Tihu) volcanic activity.

Overall, the studied MIs are hosted by olivines whose forsterite content ranges from that close to equilibrium with mantle peridotite (Fo $>88 \mathrm{~mol} \%$; e.g. Arai 1994) to that of more olivine-fractionated melts. The mineral chemistry described above allows for identification of the earliest liquidus phases, which crystallised prior to melt modification processes such as magma mixing, shallow-level crustal assimilation and fractional crystallisation. Because REEs and many other trace elements are highly incompatible in olivine (e.g. de Hoog et al. 2010), and olivine crystallisation induces no discernible fractionation among them, most incompatible trace-element ratios in MIs enclosed by the most forsteritic olivines have remained unchanged and therefore represent those of the (near-)primary melts from which they originate. Hence, for discussion on source characteristics and mantle melting, we include only those MIs hosted by olivines with Fo $>80 \mathrm{~mol} \%$, i.e. melt entrapped during the incipient stages of olivine crystallisation, relatively shortly after melt segregation from the mantle source.

Given the scarcity of olivine and olivine-hosted MIs in the K-alkaline products of Bixad and Malnaș, primitive clinopyroxene phenocrysts (with $\mathrm{Mg \#}$ up to $92 \mathrm{~mol} \%$ ) may alternatively offer a window into the melt source. To ensure crystallisation from the most primitive magmas, only data from clinopyroxenes with $\mathrm{Mg \#}>89 \mathrm{~mol} \%$ are considered for discussion. Because its crystallisation and composition is sensitive to pressure (e.g. Langmuir et al. 1992), the existence of high-Mg\# (90-92 mol\%) clinopyroxene phenocrysts at Bixad and Malnaș is demonstrative of relatively deep crystallisation from the parental magma, possibly at depths of the crust-mantle boundary (Laumonier et al. 2019).

\section{Calc-alkaline magmatism in Călimani}

Fractionation and crustal assimilation are ubiquitous processes in the magmatic plumbing system beneath Călimani, Gurghiu and Harghita (Mason et al. 1995, 1996). Based on whole-rock major and trace element and isotopic constraints, their mantle sources have been interpreted to be modified by sediment-derived components extracted from the subducted slab (Mason et al. 1996). Similar inferences have been made for the Miocene post-collisional volcanic products of OașGutâi to the northwest (Kovacs et al. 2017). However, the probable underthrust nature of the accretionary prism is likely to have allowed magmas to assimilate material similar to subducted sediments at crustal levels (Mason et al. 1996). Hence, the exact distinction between subduction enrichment and lower-crustal MASH (melting, assimilation, storage, homogenisation) processes was hampered by the study of bulk rocks alone (Seghedi et al. 1995; Mason et al. 1996).

\section{Călimani: mantle source modification by sediment-derived melts}

Primitive Călimani melts unequivocally demonstrate that their enriched signature, exemplified by $\mathrm{Th} / \mathrm{Yb}$ (and $\mathrm{Th} / \mathrm{Y}$; Fig. $7 \mathrm{a}), \mathrm{Th} / \mathrm{Nb}$ and $\mathrm{Ce} / \mathrm{Pb}$, and various LILE/HFSE ratios, is a feature inherent to the parental magmas. Hence, they elucidate previously ambiguous source signals, and provide 

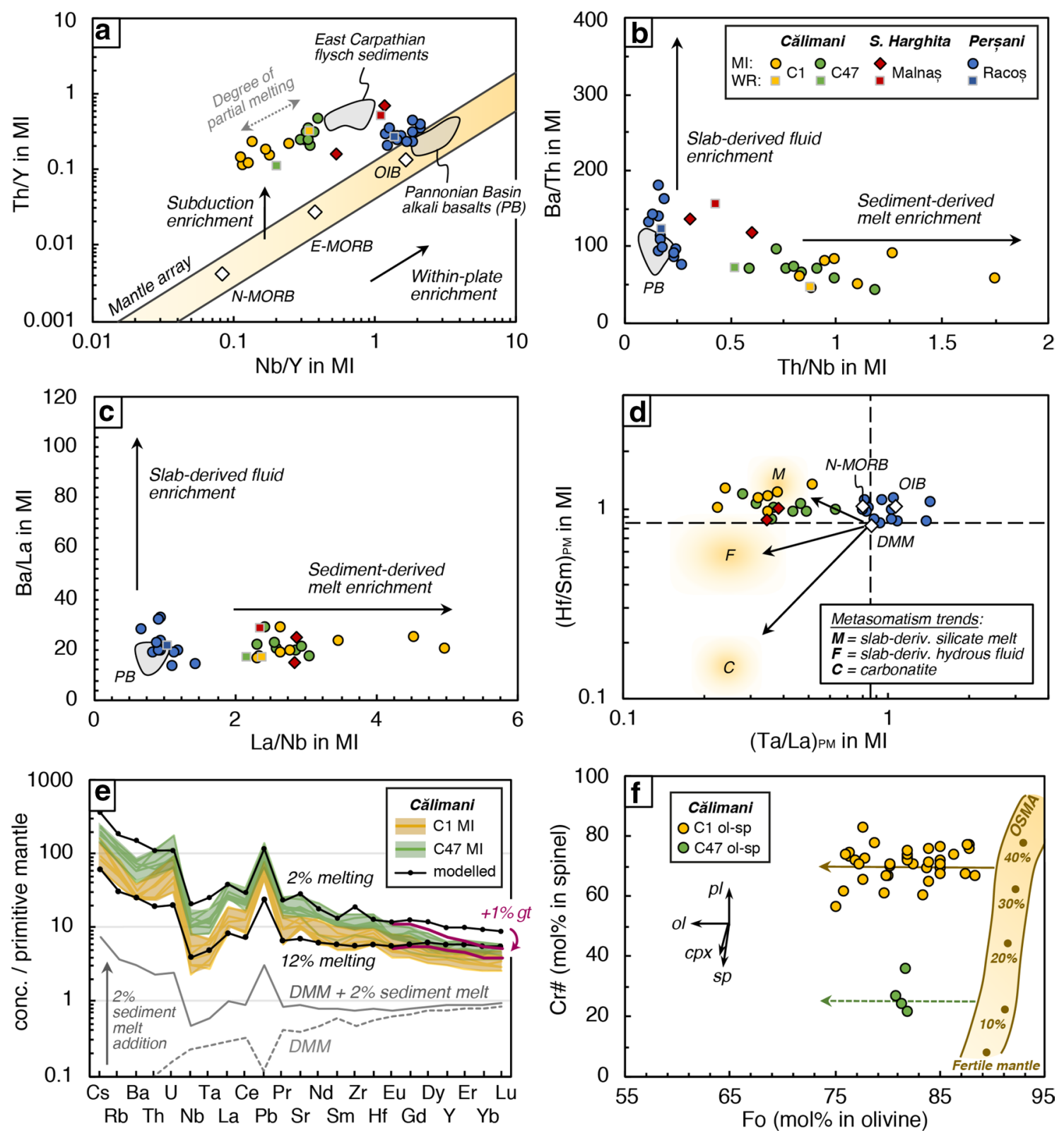

Fig.7 Evaluation of mantle source characteristics for Călimani, Southern Harghita (Bixad and Malnaș) and Perșani (Racoș). a Nb/Y versus $\mathrm{Th} / \mathrm{Y}$ in olivine-hosted melt inclusions (MIs). WR $=$ wholerock hosts. Mantle array is based on the compositions of Sun and McDonough (1989). Black arrows indicate directions of subduction and within-plate enrichment (Pearce and Peate 1995). East Carpathian flysch sediments are from Mason et al. (1996); Pannonian Basin alkali basalts from Embey-Isztin et al. (1993). b Th/ $\mathrm{Nb}$ versus $\mathrm{Ba} / \mathrm{Th}$ and $\mathbf{c} \mathrm{La} / \mathrm{Nb}$ versus $\mathrm{Ba} / \mathrm{La}$, illustrating trends for sedimentderived melt and slab-derived fluid enrichment of the mantle source (e.g. Kent and Elliott 2002). d Ta/La versus $\mathrm{Hf} / \mathrm{Sm}$ normalised to primitive mantle (PM; McDonough and Sun 1995). Trends for melt(M) and fluid-related (F) subduction enrichment and carbonatite (C) metasomatism are based on La Flèche et al. (1998) and references

therein; depleted MORB mantle (DMM) composition is from Workman and Hart (2005). e PM-normalised incompatible trace-element patterns for modelled non-modal batch melts ( 2 and 12\%; black lines with dots) compared with those of olivine-hosted MIs from Călimani. Purple lines illustrate the effect of adding 1\% garnet to the source in the model (as discussed in the main text). DMM (Workman and Hart 2005) and DMM $+2 \%$ sediment-derived melt (GLOSS-II; Plank 2014) are shown for comparison. f Host-olivine forsterite (Fo) content versus $\mathrm{Cr} \#(\mathrm{~mol} \%)$ of their Cr-spinel inclusions in Călimani. Olivine-spinel mantle array (OSMA) and melting trend (annotated with melting percentages) are from Arai (1994). Black arrows indicate expected fractionation trends for olivine (ol), clinopyroxene (cpx), spinel (sp) and plagioclase (pl) from Smith and Leeman (2005) 
evidence for mantle source enrichment by a sedimentderived component. Such a metasomatic component may be a melt or an aqueous fluid. Whilst HFSEs and Th are relatively immobile in aqueous fluids, the budget of Th in subduction-related rocks has been shown to be controlled mainly by sediment recycling, meaning high $\mathrm{Th}, \mathrm{Th} / \mathrm{Nb}$ and Th/REE are indicative for sediment-derived melts (Elliott et al. 1997; Hawkesworth et al. 1997; Plank and Langmuir 1998; Plank 2005). The enrichment of such melts in Th and incompatible trace elements, whilst still being depleted in HFSEs, likely pertains to residual rutile during partial melting of sediments at the slab-mantle wedge interface (Elliott et al. 1997; Kessel et al. 2005; Tommasini et al. 2007). Călimani MIs exhibit elevated Th/Nb (Fig. 7b) and La/Nb (Fig. 7c) at invariably low $\mathrm{Ba} / \mathrm{Th}$ and $\mathrm{Ba} / \mathrm{La}$, respectively, consistent with the addition of slab-sediment-derived melts to the mantle source region beneath Călimani. This is further supported by the inverse covariation between PM-normalised $\mathrm{Ta} / \mathrm{La}$ and $\mathrm{Hf} / \mathrm{Sm}$ ratios, which form a trend associated with melt-related metasomatism (La Flèche et al. 1998).

\section{Călimani: partial melting of an enriched mantle source}

The nature of the Călimani magma source, the extent of partial melting and the possible involvement of garnet during melting can be constrained by incompatible trace-element systematics in primitive olivine-hosted MIs. Relatively low MREE/HREE values $(\mathrm{Sm} / \mathrm{Yb}=1-2.5)$ indicate a limited role for residual garnet in the source. On the whole, the trace-element budget of the MIs, as well as wholerock isotopic signatures (Mason et al. 1996), suggest that the affected East Carpathian mantle was compositionally close to the depleted-MORB mantle (DMM; Workman and Hart 2005). Sediment addition to the source, as evidenced by selective trace-element enrichment, was approximated by adding a melt phase derived from Global Subducting Sediment (GLOSS-II; Plank 2014) to DMM (Workman and Hart 2005), using crystal/melt partition coefficients for subducting sediments (at $2 \mathrm{GPa}, 900{ }^{\circ} \mathrm{C}$ ) from Johnson and Plank (1999). Non-modal batch melting (Shaw 1970) was modelled using mineral proportions in DMM $\left(\mathrm{Ol}_{0.57} \mathrm{Opx}_{0.28} \mathrm{Cpx}_{0.13} \mathrm{Sp}_{0.02}\right)$ by Workman and Hart (2005), melting reaction $\left(\mathrm{Cpx}_{0.82}+\mathrm{Opx}_{0.40}+\mathrm{Sp}_{0.08}=\mathrm{Melt}_{1.0}+\mathrm{Ol}_{0.30}\right.$ for a spinel lherzolite at $1 \mathrm{GPa}$ ) by Kinzler and Grove (1992) and mineral/melt partition coefficients by Gibson and Geist (2010, and references therein).

Modelling indicates that the incompatible trace-element patterns of Călimani C1 and C47 melts can be closely replicated by $\sim 2$ to $12 \%$ partial melting of a DMM source to which $2 \%$ sediment-derived (GLOSS-II-type) melt was added (Fig. 7e). Relatively high LREE/MREE in sample $\mathrm{C} 47(\mathrm{La} / \mathrm{Sm}=3.3-5.9)$ suggest lower $(\sim 2-6 \%)$ degrees of partial melting than for $\mathrm{C} 1(\mathrm{La} / \mathrm{Sm}=2.4-3.5)$, which requires 4-12\% melting. Slight MREE/HREE fractionation for both can additionally be simulated by adding 1\% garnet to the mantle source (purple lines in Fig. 7e). The calculated degrees of melting are largely similar to those inferred for regional subduction-related post-collisional volcanics, such as in western Anatolia (Aldanmaz et al. 2000) and peninsular Italy (Peccerillo 2017, and references therein). The variability in melt compositions evident in Fig. $7 \mathrm{a}$ is principally controlled by the extent of partial melting, as the trace-element ratios characteristic for sediment input overlap for $\mathrm{C} 1$ and $\mathrm{C} 47$ (Fig. 7b-d).

\section{Călimani: source heterogeneity revealed by Cr-spinel}

The $\mathrm{Cr} \#$ of spinel in primitive magmas is considered to reflect the modal composition of the mantle source (Dick and Bullen 1984; Arai 1994), and is widely used to characterise the fertile (low $\mathrm{Cr} \#$ ) or refractory (high $\mathrm{Cr} \#$ ) nature of MORB, OIB or subduction-related magma sources. Contrasting Cr\# in Cr-spinels from Călimani samples $\mathrm{C} 1$ and $\mathrm{C} 47$ (average $=71$ and $27 \mathrm{~mol} \%$, respectively), hosted by olivines with Fo $>75 \mathrm{~mol} \%$, plot along distinct fractionation trends originating from the olivine-spinel mantle array (OSMA) of Arai (1994). Similarly high Mg\# in both spinel groups (up to $60 \mathrm{~mol} \%$ ) indicate that the difference in $\mathrm{Cr} \#$ is mantle-derived. This may in turn reflect contrasting extents of melt extraction/mantle depletion and/or pressure conditions (Arai 1994, and references therein). Modest differences in melting extent ( 2-6 versus 4-12\%) alone cannot ccount

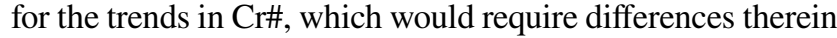
to be significantly larger, i.e. 10 versus $40 \%$ (Jaques and Green 1980; Matsukage and Kubo 2004). Furthermore, the difference in Cr\# in Călimani appears to be unrelated to pressure differences during melt extraction (Niu et al. 2011), as testified by high-Fo olivine compositions (higher $\mathrm{Ni} / \mathrm{Mg}$, $\mathrm{Ni} /(\mathrm{Mg} / \mathrm{Fe})$ and $\mathrm{Ni}$ in $\mathrm{C} 1$; Online Resource Fig. A2). Therefore, $\mathrm{C} 1$ spinels likely inherited their elevated $\mathrm{Cr} \#$ signature from lower-pressure mantle restites (Dick and Bullen 1984; Allan et al. 1988). This could potentially be tied to a melt extraction (depletion) event prior to Neogene-Quaternary magmatic activity. We infer that the parental melts of $\mathrm{C} 1$ and $\mathrm{C} 47$ were derived from distinct mantle source domains beneath Călimani, marked by contrasting source fertility, which possibly represents a relic of ancient melt extraction.

\section{K-alkaline magmatism in Southern Harghita}

Shoshonitic magmatism occurred at Bixad ( 907 ka) and Malnaș ( 964 ka) in the midst of (high-K) calc-alkaline activity in Southern Harghita and Na-alkaline activity in Perșani (Panaiotu et al. 2013; Molnár et al. 2018). Such diverse, contemporaneous magmatic occurrences suggest a significant change in the mantle source with respect to 
the older, calc-alkaline CGH segment. The shoshonites of Bixad and Malnaș display hybrid mineralogical assemblages indicative of extensive mixing of mafic magmas with more evolved magmas at crustal levels (Mason et al. 1996; Seghedi et al. 2011). High LILE/HFSE ratios and distinctive trace-element enrichments in whole rocks have been interpreted as evidence for fluid components in the source and high-pressure fractionation (Seghedi et al. 2004a, 2005), as well as source fertilisation by adakite-like melts and asthenospheric melt components (Seghedi et al. 2011). Their exact provenance, however, has so far remained ambiguous.

\section{Southern Harghita: calculation of melts in equilibrium with Mg-rich clinopyroxene}

The Mg-rich clinopyroxenes from Bixad and Malnaș (with Mg\# up to 92 mol\%) can be used to calculate the compositions of the melts with which they are in equilibrium. Clinopyroxene is host to a considerable amount of incompatible elements and thus its partitioning behaviour exerts significant control over the composition of the residual melt (e.g. Sobolev et al. 1996). Because this behaviour is sensitive to pressure, temperature, oxygen fugacity, melt type and degree of melt fractionation (Blundy and Wood 2003), it is important to consider the variability in clinopyroxene/melt partition coefficients $\left(D_{\text {cpx/melt }}\right)$. A set of experimental data on $D_{\text {cpx/melt }}$ for basaltic systems over a range of temperatures and pressures was therefore compiled from the literature (Hart and Dunn 1993; Hauri et al. 1994; Sobolev et al. 1996; Blundy et al. 1998; Johnson 1998; Gaetani et al. 2003; Tuff and Gibson 2007; Suzuki et al. 2012; Laubier et al. 2014). To estimate the compositions of the equilibrium melts, the $D$ values were averaged for a given element or, in case few or disparate values were reported, selected from a single study (Online Resource Fig. A4). Despite the variance in $D$ values, reflective of the variability in melt (and clinopyroxene) compositions and crystallisation conditions, the overall patterns are sub-parallel. Hence, they allow for examination and comparison especially of relative trace-element abundances in the equilibrium melts; both between Bixad and Malnaș, and with respect to olivine-hosted MIs from Malnaș.

\section{Southern Harghita: hydrous metasomatic phases in the source}

The compositions of melts in equilibrium with $\mathrm{Mg}$-rich clinopyroxenes from Bixad and Malnas show very high $\mathrm{Sr} / \mathrm{Y}$ (Fig. 8a) and La/Yb ratios at relatively low $\mathrm{Y}$ and $\mathrm{Yb}$ content, respectively. This is indicative of a strong adakitelike affinity, which is also observed in the bulk lavas (Mason et al. 1996; Seghedi et al. 2004a) and olivine-hosted MIs (Fig. 6c). The absence of inverse covariations between Mg\# (70-92 $\mathrm{mol} \%)$ and these ratios in clinopyroxene (Online
Resource Fig. A3b) demonstrates that clinopyroxene and/ or amphibole fractionation (e.g. Macpherson et al. 2006; Castillo 2012) does not govern the adakite-like features of these products.

Experimental studies have shown that metasomatic minerals such as pargasitic amphibole, phlogopite, orthopyroxene, clinopyroxene and garnet are formed during highpressure interactions between ultramafic parageneses and silicate liquids (e.g. Prouteau et al. 2001; Rapp et al. 1999; Sen and Dunn 1995). Whilst strong MREE/HREE fractionation may be indicative of residual garnet, features such as elevated $\mathrm{Sr} / \mathrm{Y}$ can also result from involvement of amphibole in the melt source. The distinctive and singular enrichment in e.g. $\mathrm{K}, \mathrm{Rb}, \mathrm{Ba}$ and $\mathrm{Sr}$ at Bixad and Malnaș suggests a role for LILE-rich (hydrous) mineral phases in the mantle source. These elements are preferentially incorporated into pargasitic amphibole and phlogopite, i.e. minerals commonly observed in metasomaticallyenriched arc-derived mantle xenoliths (e.g. Schiano et al. 1995; Kepezhinskas et al. 1995) and also in xenoliths from the Carpathian-Pannonian region (e.g. Szabó et al. 2004). Although these minerals share incompatible trace-element features, there are key differences that allow for discrimination. Whereas metasomatic phlogopite typically hosts relatively small amounts of HFSEs and REEs, but is rich in $\mathrm{Rb}$ and $\mathrm{Ba}$, amphibole contains little $\mathrm{Rb}$ (and $\mathrm{Ba}$ ) and more HFSEs and LREEs (e.g. Ionov and Hofmann 1995). Particularly useful is the difference in compatibility of $\mathrm{Rb}$ and $\mathrm{Ba}$, which are compatible in phlogopite, yet mildly incompatible in amphibole (LaTourrette et al. 1995; Pilet et al. 2011).

Malnaş MIs show high $\mathrm{Ba} / \mathrm{Rb}$ (19-31) and low $\mathrm{Rb} / \mathrm{Sr}$ (0.02-0.03), distinct from Călimani MIs. Clinopyroxene (Mg\# 89-92 mol\%) equilibrium melts for both Bixad and Malnaș exhibit positive covariations between $\mathrm{Zr}$ and $\mathrm{Zr} / \mathrm{Rb}$ (Fig. 8b), as well as $\mathrm{Nb}$ and $\mathrm{Nb} / \mathrm{Rb}$ (Fig. 8c). These systematics point to a prominent role for amphibole in the source (e.g. Francis and Ludden 1995; Furman and Graham 1999; Dalpé and Baker 2000). Divergent trends in $\mathrm{Ba} / \mathrm{Rb}$ and $\mathrm{Rb} / \mathrm{Sr}$ (Fig. 8d), ratios which increase with the increasing influence of residual amphibole and phlogopite, respectively (Furman and Graham 1999), indicate a more pronounced role for amphibole in the Bixad source, and suggest a minor contribution from phlogopite to Malnaș melts. These features are corroborated by the average clinopyroxene compositions from both locations (Fig. 8e), which show that, compared to Malnaș, Bixad clinopyroxenes display lower $\mathrm{Rb}, \mathrm{Ba}, \mathrm{Rb} / \mathrm{Sr}$ and HFSEs ( $\mathrm{Ti}, \mathrm{Nb}, \mathrm{Ta}, \mathrm{Zr}, \mathrm{Hf}$ ) with respect to neighbouring REEs, as well as higher $\mathrm{Ba} / \mathrm{Rb}, \mathrm{Nb} / \mathrm{Ta}$, MREE/HREE, LREE and MREE content. The increased influence of amphibole on Bixad melts is tied to a lower degree of partial melting, evidenced by higher LREE/MREE compared to Malnaș (e.g. $\mathrm{La} / \mathrm{Sm}=1.2-1.4$ versus $1.0-1.2$ in clinopyroxene with 

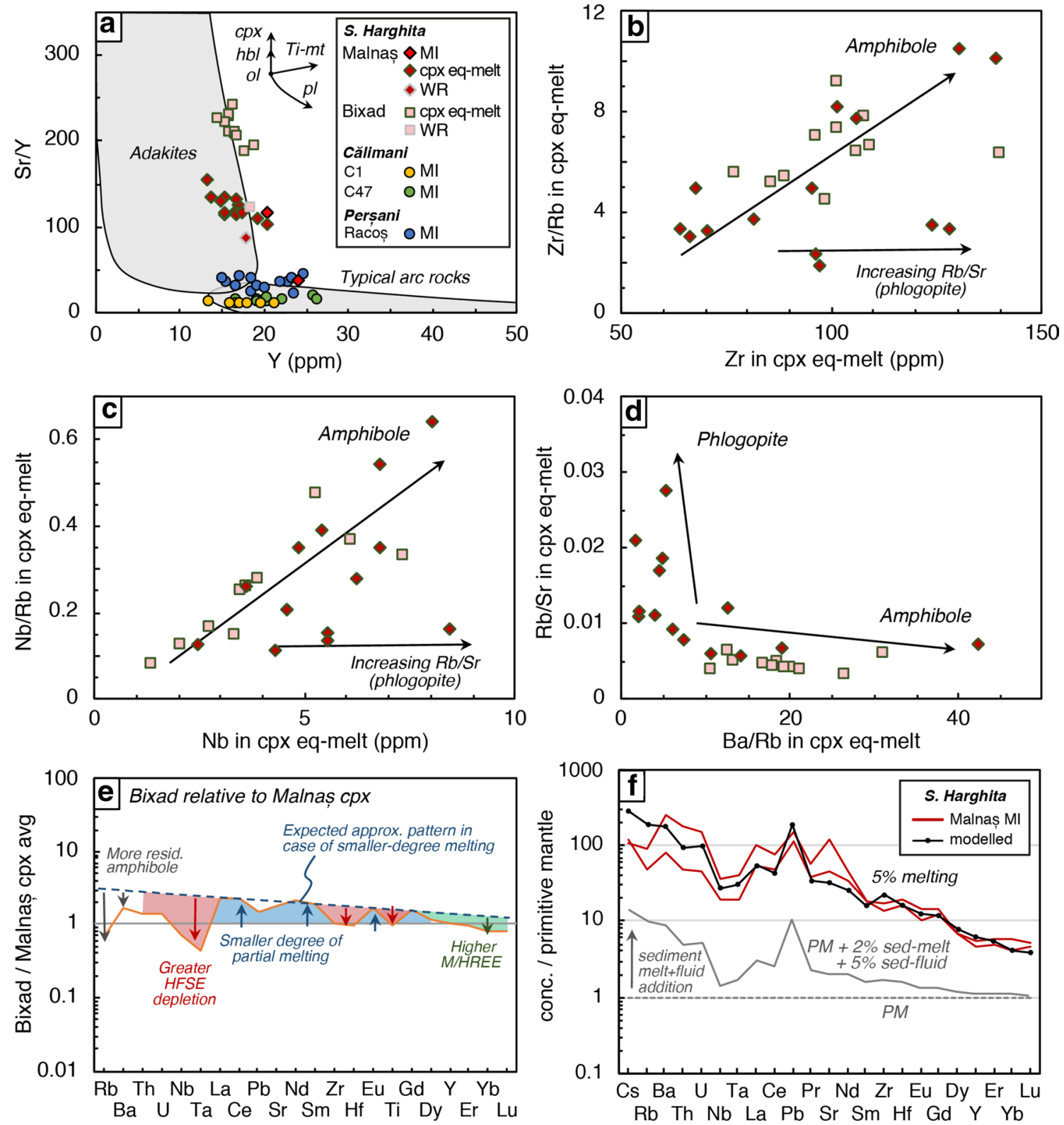

Fig. 8 Characteristics of primitive melts and their mantle source based on trace elements in Mg-rich clinopyroxene phenocrysts and olivine-hosted melt inclusions (MIs) from Bixad and Malnaș (Southern Harghita). a $\mathrm{Y}$ (ppm) versus $\mathrm{Sr} / \mathrm{Y}$ for clinopyroxene (Mg\#>89 mol\%) equilibrium melts ('cpx eq-melts'), with fields for adakite and typical arc rocks (Defant and Drummond 1990). Compositions of MIs (in olivine with Fo $>80 \mathrm{~mol} \%$ ) and whole-rock hosts (WR) are also shown. Crystal fractionation paths for olivine (ol), clinopyroxene (cpx), hornblende (hbl), plagioclase (pl) and Ti-magnetite (Ti-mt) are from Castillo et al. (1999). b $\mathrm{Zr}$ (ppm) versus $\mathrm{Zr} /$ $\mathrm{Rb}$; and $\mathrm{c} \mathrm{Nb}$ versus $\mathrm{Nb} / \mathrm{Rb}$ in cpx eq-melts from Bixad and Malnaș, illustrating the control of amphibole on melt compositions (cf. Dalpé and Baker 2000). $\mathbf{d ~ B a} / \mathrm{Rb}$ versus $\mathrm{Rb} / \mathrm{Sr}$ in cpx eq-melts of Bixad and

Malnaș, illustrating trends for phlogopite and amphibole melting in the source (after Furman and Graham 1999). Note the absolute values of concentrations (and their ratios) in the cpx eq-melts depend on the choice of partition coefficients (see main text; Online Resource Fig. A4), and should therefore be taken as indicative; the relative trends, on the other hand, are independent from such choices. e Averaged clinopyroxene trace-element composition (Mg\#>89 mol\%) for Bixad with respect to (i.e. normalised to) Malnaș. f Primitive mantle (PM)-normalised (McDonough and Sun 1995) incompatible traceelement patterns for modelled non-modal batch melts (5\%) compared with Malnaș MIs (in olivine with $\mathrm{Fo}_{82}$ ). Compositions of PM (McDonough and Sun 1995) and PM+sediment (GLOSS-II; Plank 2014)-derived melt (2\%) and fluid (5\%) are shown for comparison 


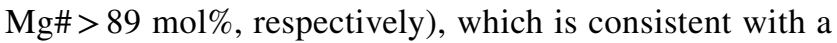
scenario where amphibole is only partly consumed during melting. Even within Malnaș MIs, enclosed by a single olivine, significant differences are apparent in $\mathrm{Ba} / \mathrm{Rb}$ and $\mathrm{Rb} / \mathrm{Sr}$ (Fig. 6c), suggesting the compositional variability in primitive melt batches to be linked to different contributions of amphibole and phlogopite.

These characteristics, observed in the highest-Mg\# clinopyroxenes and olivine-hosted MIs, thus represent a primitive feature inherent to the (mafic) parental melts beneath Bixad and Malnaș, rather than one dominantly derived from later magma mixing in crustal reservoirs or from high-pressure crystal fractionation at lower crustal levels. We infer that metasomatic enrichment of the mantle by hydrous fluids dehydrated from the subducted slab (e.g. Castillo 2008), which produces a LILE-enriched mantle mineralogy including amphibole ( \pm phlogopite), is the principal cause of the anomalously potassic, adakite-like signatures in Southern Harghita. Lithospheric mantle xenoliths brought up in close proximity, in Perșani (e.g. Faccini et al. 2020; Vaselli et al. 1995), provide evidence for just such a process beneath the area.

\section{Southern Harghita: partial melting of a metasomatised mantle source}

The previous section demonstrates that models of mantle melting beneath Bixad and Malnaș require a LILE-enriched, amphibole-bearing source. Malnaș MIs exhibit trace-element signatures (e.g. Fig. 6c) that suggest derivation from an enriched mantle source close to PM (McDonough and Sun 1995). Considerable MREE/HREE fractionation (Sm/ $\mathrm{Yb}=3-4)$ further suggests residual garnet in the source. Hence, we tentatively consider a PM source composition (McDonough and Sun 1995) with mineral proportions $\left(\mathrm{Ol}_{0.56} \mathrm{Opx}_{0.25} \mathrm{Cpx}_{0.14} \mathrm{Gt}_{0.03} \mathrm{Am}_{0.02}\right)$, modified to contain amphibole after $\mathrm{Ma}$ et al. (2011), and melting reaction $\left(\mathrm{Ol}_{0.05}+\mathrm{Opx}_{0.05}+\mathrm{Cpx}_{0.30}+\mathrm{Gt}_{0.20}+\mathrm{Am}_{0.40}=\mathrm{Melt}_{1.0}\right.$ for amphibole-bearing garnet peridotite) by Barry et al. (2003), and use mineral/melt partition coefficients as in the Călimani section above, with the addition of those for amphibole by Pilet et al. (2011). As for Călimani, metasomatic enrichment of the source was approximated by adding a melt phase derived from Global Subducting Sediment (GLOSSII; Plank 2014), using crystal/melt partition coefficients for subducting sediments (at $2 \mathrm{GPa}, 900{ }^{\circ} \mathrm{C}$ ) from Johnson and Plank (1999). Given the elevated concentrations of $\mathrm{K}$ and other LILEs, additional enrichment was modelled by adding a fluid phase derived from GLOSS-II, using the crystal/ fluid partition coefficients for $2 \mathrm{GPa}$ and $700{ }^{\circ} \mathrm{C}$ (Johnson and Plank 1999).

Most of the incompatible trace-element features of Malnaș MIs can be obtained by $\sim 5 \%$ partial melting of a
PM source to which both sediment-derived (GLOSS-II-type) melt (2\%) and fluid (5\%) was added (Fig. 8f). Exceptions are the most-incompatible elements, $\mathrm{Cs}$ and $\mathrm{Rb}$, whose over-predicted concentrations probably result from their sensitivity to (1) mineral/melt element partitioning; (2) the magnitude of source enrichment; (3) the nature of the subducted sediment; and (4) the possible role of residual minor phases in the source. The principal result of the modelling is that Malnaș melts are compatible with a source enriched by sediment-derived melts and fluids, and with extraction at depths were garnet is present. The latter suggests that the source region was located deeper than that of the CGH calcalkaline melts to the northwest.

\section{Na-alkaline magmatism in Perșani}

Na-alkaline volcanism in Perșani occurred contemporaneously with (high-K) calc-alkaline and shoshonitic magmatism $35 \mathrm{~km}$ eastward in Southern Harghita (Downes et al. 1995; Panaiotu et al. 2004; Harangi et al. 2013; Molnár et al. 2018). Perșani lavas appear to reflect melt derivation from an OIB-like, asthenospheric source (Downes et al. 1995; Seghedi et al. 2004b, 2011). The ultramafic mantle xenoliths entrained in the magmas have been interpreted to reflect re-fertilisation of the lithospheric mantle by a subductionrelated melt and interaction with an alkaline metasomatic agent (Faccini et al. 2020; Downes et al. 1995; Vaselli et al. 1995). Perșani basalts collectively exhibit minor, though distinct, compositional enrichments compared to other alkali basalts in the Pannonian Basin, a feature which has been ascribed to a subduction-related component beneath the area (Embey-Isztin et al. 1993; Downes et al. 1995; Embey-Isztin and Dobosi 1995; Seghedi et al. 2004b). These bulk-lava studies, however, could not resolve whether the anomalous signature is inherent to the asthenospheric source or resulted from interaction with the overlying lithosphere.

\section{Perșani: a pyroxenitic source for low-Ca olivine?}

Several observations, such as the elemental trends in olivine (Fig. 3b; cf. Herzberg et al. 2013; Hole 2018), horizontal trends of Cr-spinel Cr\# (Fig. 9a) and estimated crystallisation temperatures (Harangi et al. 2013), suggest that early-stage olivine crystallisation beneath Perșani was not accompanied by (high-pressure) crystallisation of clinopyroxene. Of particular interest is a sub-population of Racoș olivines marked by low $\mathrm{CaO}(<0.1 \mathrm{wt} \%$; Fig. 3b) and $\mathrm{Cr}$ $(<140 \mathrm{ppm})$, which seems to be of different origin. Such low $\mathrm{Ca}$ and $\mathrm{Cr}$ abundances in high-Fo (90-92 mol\%) olivines from intra-continental alkaline basalts are commonly interpreted to reflect a xenocrystic origin, e.g. from lithospheric mantle peridotites (e.g. Boudier 1991; Hirano et al. 2004), and have indeed been reported for other Perșani olivines 

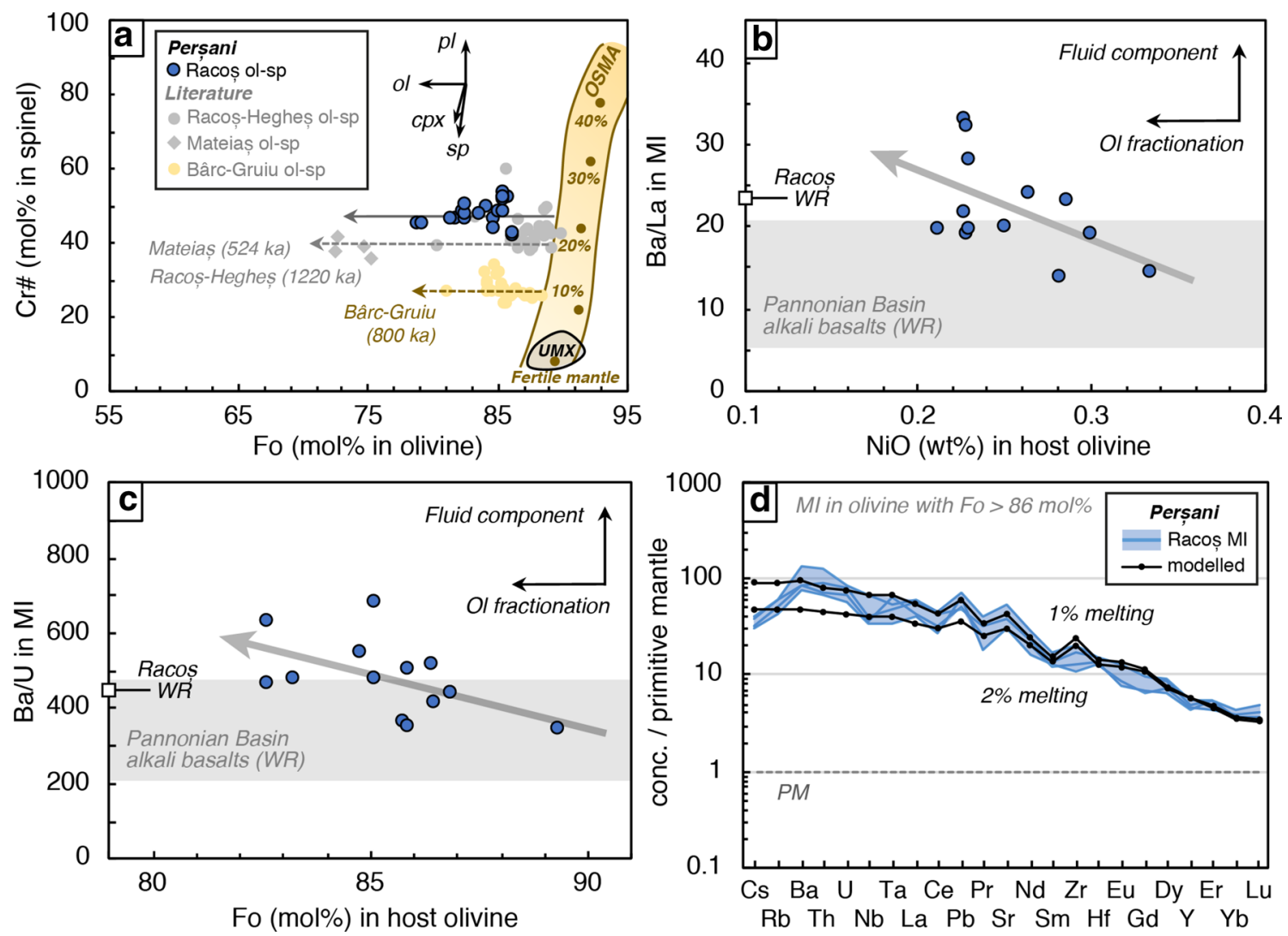

Fig. 9 Constraints on mantle source characteristics, primitive melts and melting beneath Perșani. a Host-olivine forsterite (Fo) content versus $\mathrm{Cr} \#(\mathrm{~mol} \%)$ of their spinel inclusions. Olivine-spinel mantle array (OSMA) and melting trend (annotated with melting percentages) are from Arai (1994). Black arrows indicate expected fractionation trends for olivine (ol), clinopyroxene (cpx), spinel (sp) and plagioclase (pl) from Smith and Leeman (2005). UMX=spinels in olivines from ultramafic xenoliths in Perşani (Vaselli et al. 1995; Falus et al. 2008). Published Perșani olivine-spinel data are from Harangi et al. (2013). Fractionation indices ( $\mathrm{NiO}$ in $\mathrm{wt} \%$ and $\mathrm{Fo}$ in $\mathrm{mol} \%$ ) of host olivine against $\mathbf{b} \mathrm{Ba} / \mathrm{La}$, and $\mathbf{c} \mathrm{Ba} / \mathrm{U}$ in primitive oli-

vine-hosted MIs. Shown for comparison are the trace-element ratios of Racoș whole-rocks (WR; Downes et al. 1995; Harangi et al. 2013) and those of the Pannonian Basin alkali basalts (grey field; $\mathrm{MgO}>8$ wt $\%$ and $\mathrm{SiO}_{2}<52 \mathrm{wt} \%$; Harangi et al. 2015, and references therein). Black arrows illustrate directions expected for melts affected by olivine fractionation and/or fluid enrichment alone (see main text for discussion). Grey arrows indicate linear trend lines. d Primitive mantle-normalised (PM; McDonough and Sun 1995) incompatible traceelement patterns for modelled non-modal batch melts (1 and $2 \%$ ) and for Racos MIs in olivine with Fo > $86 \mathrm{~mol} \%$

(Vaselli et al. 1995; Falus et al. 2008; UMX in Fig. 3) and for the western Pannonian Basin (Jankovics et al. 2019). Yet a previously undocumented fractionation continuum present in this new group (Fig. 3b), and their overall elemental signature clearly unlike xenolithic olivine (Online Resource Fig. A2), argue against a non-magmatic (i.e. xenocrystic) origin. They collectively exhibit low $\mathrm{Ca} / \mathrm{Fe}(\mathrm{Ca} / \mathrm{Fe} \times 100=0.1-0.7)$ and higher $\mathrm{Fe} / \mathrm{Mn}(60-105), \mathrm{Ni} / \mathrm{Mg}(\mathrm{Ni} / \mathrm{Mg} \times 100$ up to $1.14)$ and $\mathrm{Ni} /(\mathrm{Mg} / \mathrm{Fe})[\mathrm{Ni} /(\mathrm{Mg} / \mathrm{Fe}) / 1000$ up to 1.2$]$ compared to the higher-Ca group (Online Resource Fig. A2), suggesting that they either started crystallising from higher-pressure parental melts (Niu et al. 2011) or from melts derived from a more pyroxenitic source (Sobolev et al. 2007). The particularly low $\mathrm{Ca}$, and $\mathrm{Ca} / \mathrm{Fe}$, as well as the uniformly low $\mathrm{Cr}$,

favour the latter scenario, as systematic covariations between the proxies listed above are not observed.

It should be noted that even the 'higher'-Ca group olivines exhibit lower $\mathrm{Ca}$ content than typical intraplate OIB-type olivines (e.g. Herzberg 2011). The compositions in this group are similar to those of the Perşani olivines reported by Harangi et al. (2013), who argued against the presence of pyroxenite (retaining $\mathrm{Ca}$ ) in their source on the basis of concomitantly low $\mathrm{Ni}$ and high $\mathrm{Mn}$ content, the opposite of which is expected in the case of pyroxenite melting (Sobolev et al. 2007). Instead, they suggest its signature could have been induced by the lithospheric thickness (the 'lid-effect'; Niu et al. 2011), although this notion cannot account for the overall deficiency in $\mathrm{Ca}$. Although the lid-effect may be operative, we suggest that 
the low $\mathrm{Ca}$ content of olivine may instead be related to the influence of water on the partitioning of Ca between olivine and melt (e.g. Gavrilenko et al. 2016), and/or the particularly low degrees of partial melting (see below).

\section{Perșani: spatial variability in source fertility revealed by Cr-spinel}

Cr-spinel inclusions, observed in 'higher'-Ca group olivines, as well as those reported by Harangi et al. (2013), show higher values of $\mathrm{Cr} \#$ than reported for ultramafic lithospheric xenoliths from the area (Vaselli et al. 1995; Falus et al. 2008), which cluster around the low-Cr\# 'fertile' mantle value of Arai (1994). This suggests that the magmatic spinels originate from a source whose modal composition was affected by prior melt extraction in the range of $\sim 10$ to 25\% (Fig. 9a). Harangi et al. (2013) observed two olivinespinel groups, corresponding to samples from Racoș-Hegheș (1221 ka; Panaiotu et al. 2013) and Bârc-Gruiu (800 ka; Panaiotu et al. 2004, 2013), and inferred a temporal trend. However, the overlapping fractionation trends of the adjacent centres of Mateiaș (684 ka; Panaiotu et al. 2013) and Racoș (Fig. 9a) point to a spatial, rather than temporal, association of mantle depletion. The contrasting extents of mantle depletion are thus an intrinsic feature of the source region beneath Perşani, and not a temporal product of low-volume intraplate magmatism. Interestingly, these eruptive centres are separated by only $\sim 10 \mathrm{~km}$ in NE-SW direction and, as such, demonstrate that the refractory nature of intraplate magma sources may show considerable lateral variations, even at small scales.

\section{Perșani: interaction of asthenospheric melts with metasomatic components}

The presence of large compositional variability in the Perșani MIs hosted by olivine with Fo $>82$ mol\% indicates that the parental melts were not uniform in composition. Clear evidence for heterogeneity within the (near-)primary melt batches is given by variable $\mathrm{Nb} / \mathrm{Y}$ and $\mathrm{Th} / \mathrm{Y}$ ratios (Fig. 7a), the ranges of which exceed those of the whole rocks. The offset from the mantle array in this figure indicates chemical modification, either inherent to, or in a nascent stage after derivation from, the mantle source. Slight preferential enrichment of certain trace elements, such as $\mathrm{Ba} / \mathrm{Th}(76-180)$ at invariably low $\mathrm{Th} / \mathrm{Nb}(0.1-0.3$; Fig. $7 b)$, points to minor modification by slab-derived fluids. Compared to the average composition of OIB (Sun and McDonough 1989), Racoș MIs collectively exhibit enrichments in most LILEs and depletions in HFSEs and MREEs. These characteristics stand in marked contrast with other occurrences of alkali basalts in the Pannonian Basin (e.g. EmbeyIsztin et al. 1993).
The variability preserved in melt compositions (Fig. 7a-d) may either represent minor volumes of melt shortly after extraction from their asthenospheric source, prior to complete mixing, or the preserved incipient melt products of interaction with the subduction-modified lithospheric mantle. Inverse covariations between $\mathrm{Fo}$ as well as $\mathrm{NiO}$ content of the host olivine and (Ba, Rb,Cs)/(Th,U,Zr,LREE) ratios in the MIs (Fig. 9b, c, others in Online Resource Fig. A5) reveal an increase of LILEs over HFSEs (Th,U,Zr) and over LREEs in the parental melts during early-stage melt evolution. Many of these ratios are consequently elevated above the maximum values reported for primitive alkali basalts from the Pannonian Basin. By contrast, ratios such as LREE/ MREE or MREE/HREE show no such trends. The covariations between LILE/HFSE ratios and fractionation indices imply that the primitive melts progressively interacted with hydrous components during early-stage olivine crystallisation $\left(\mathrm{Fo}_{90}\right.$ to $\left.\mathrm{Fo}_{82}\right)$. We envisage this enrichment to have occurred during the ascent of primitive magmas through the lithosphere, which was previously metasomatised by LILE-rich fluids which precipitated hydrous phases such as amphibole. This is consistent with the amphibole-bearing lithospheric mantle xenoliths observed in Perșani, which clearly reflect enrichment by subduction-related hydrous metasomatic components (Faccini et al. 2020; Falus et al. 2008).

\section{Perșani: small-degree melting of an asthenospheric source}

In view of the interaction between primitive melts and metasomatic components during early-stage melt evolution (previous section), we model source melting by including only those MIs in olivine with Fo $>86$ (rather than 80$) \mathrm{mol} \%$. Corroborated by bulk-rock radiogenic isotope ratios (Seghedi et al. 2004b), these melts exhibit trace-element signatures (Fig. 6d) consistent with derivation from a PM-like asthenospheric source, and significant MREE/HREE fractionation $(\mathrm{Sm} / \mathrm{Yb}=2.6-4.5)$, in line with residual garnet in the source. Modelling of nonmodal batch melting (details in the Călimani section above) was therefore carried out using a PM source composition (McDonough and Sun 1995) with mineral proportions $\left(\mathrm{Ol}_{0.56} \mathrm{Opx}_{0.27} \mathrm{Cpx}_{0.14} \mathrm{Gt}_{0.03}\right)$ based on $\mathrm{Ma}$ et al. (2011) and melting reaction $\left(\mathrm{Ol}_{0.07}+\mathrm{Cpx}_{0.68}+\mathrm{Gt}_{0.25}=\mathrm{Melt}_{0.84}+\mathrm{Opx}_{0.16}\right.$ for garnet peridotite at $3 \mathrm{GPa}$ ) by Walter (1998).

The incompatible trace-element patterns of primitive Racos melts can be largely reproduced by $1-2 \%$ partial melting of a garnet lherzolite mantle source whose composition is that of the primary mantle (Fig. 9d). This estimate is slightly lower than that based on Perșani whole-rock geochemistry (2-4\%; Harangi et al. 2013), and is comparable to regional continental intraplate basalts in the Pannonian Basin (2-3\%; Harangi et al. 2015) and western Anatolia 
(Aldanmaz et al. 2006). In addition, the modelling indicates that only a moderate amount of garnet $(\sim 3 \%)$ is required to be present in the melt source, which may suggest that melting occurred in the shallow part of the garnet stability field, or in the garnet-spinel transition zone.

\section{Implications for East Carpathian geodynamics}

Many major tectonic features of the Carpathian-Pannonian region are considered to be the result of the rollback and breakoff of lithospheric slabs previously subducted along the Carpathian arc (Nemcok et al. 1998; Wortel and Spakman 2000; Sperner et al. 2001). Indeed, the remnants of such slabs are presently found on the $660-\mathrm{km}$ discontinuity beneath the region (e.g. Wortel and Spakman 2000; van der Meer et al. 2018). Slab breakoff in the East Carpathians is inferred to have occurred around $11 \pm 1 \mathrm{Ma}$ (van der Meer et al. 2018) on the basis of the arrest of shortening at 10-12 Ma in the NE Carpathians (Matenco and Bertotti 2000; Gagała et al. 2012). The only area where the subducted slab still appears to be, at least partly, attached to the surface is beneath Vrancea. Various styles of syn- and post-collisional lithospheric delamination have been invoked to account for the uplift, subsidence and active seismicity in
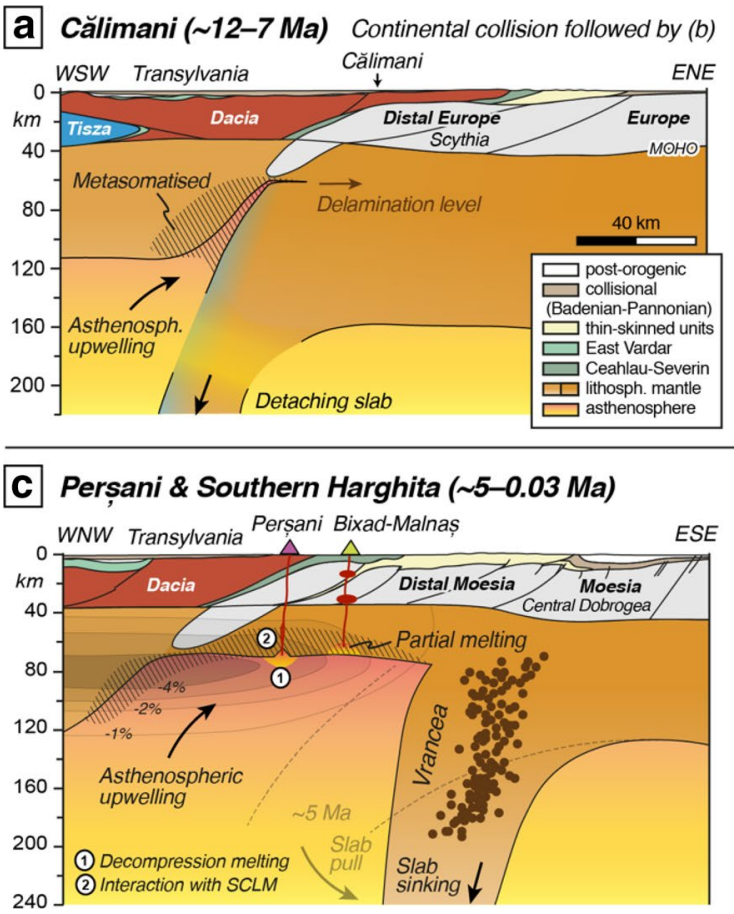

Fig. 10 Sketch of the tectono-magmatic model for the MioceneQuaternary evolution of the East Carpathians, showing asthenosphere-induced post-collisional magma generation beneath Călimani (starting at $\sim 12 \mathrm{Ma}$; a and b) and Perșani and Southern Harghita $(\sim 5-0.03 \mathrm{Ma}$; c) Vertical exaggeration is $2 \times$. Crustal-scale profiles after Matenco et al. (2010). Sub-crustal architecture in $\mathbf{c}$ is based this region (e.g. Gîrbacea and Frisch 1998; Gvirtzman 2002; Sperner et al. 2004; Knapp et al. 2005; Göğüş et al. 2016).

Petrological studies (Mason et al. 1998; Seghedi et al. 1998) have postulated progressive south-eastward slab detachment beneath the $\mathrm{CGH}$ volcanic chain as a trigger for partial melting. The notion of slab breakoff as a ubiquitous causal mechanism for melting, however, is presently challenged (Niu 2017; Garzanti et al. 2018). Although slab detachment must at some stage have occurred beneath the East Carpathians, the near-surface vertical movements recorded in and around the area do not support the putative south-eastward migration of slab breakoff during volcanism (Bertotti et al. 2003). Furthermore, in the case of slab breakoff (sensu von Blanckenburg and Davies 1995), hot asthenosphere is expected to rise and impinge upon the lithospheric mantle of the overriding plate. Also in that sense the magmatism is contradictory: its lithospheric mantle sources reflect past enrichment by subducted slab-derived material, yet the volcanic centres are superimposed onto crustal segments of the lower plate (Scythia/distal Europe), not the overriding plate (Matenco et al. 2010). It is therefore difficult to reconcile the location of volcanism (Fig. 10a), which must overlie its mantle source region, solely with the slab breakoff mechanism as previously hypothesised.
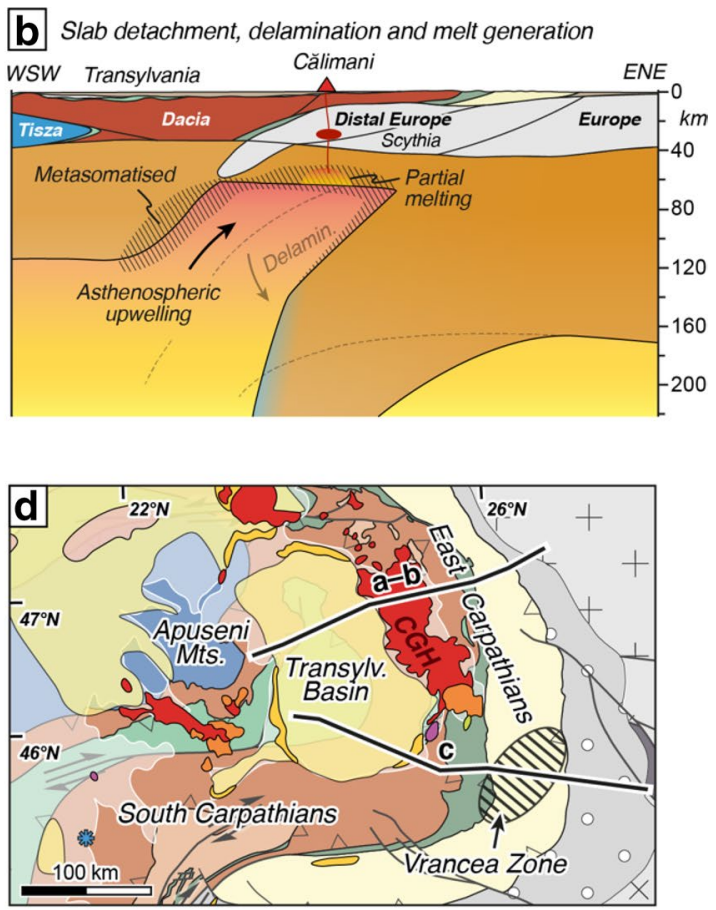

on Gîrbacea and Frisch (1998). P-wave velocity anomalies (shaded grey; annotated with percentages) in $\mathbf{c}$ after Martin and Wenzel (2006). SCLM = sub-continental lithospheric mantle. d Profile traces on the tectonic map of the Romanian Carpathians (legend as in Fig. 1a). CGH=Călimani-Gurghiu-Harghita volcanic range 
A plausible alternative mechanism is the eastward delamination of the lower lithospheric mantle (Fig. 10b), which can account for the location of volcanism (cf. Gîrbacea and Frisch 1998 for Vrancea; Seghedi et al. 1998 for the Western Carpathians). The source regions of the mafic parental melts, unequivocally located in the lithospheric mantle and not the crust, require such delamination to have occurred within the lithospheric mantle, rather than at the crust-mantle interface. The temporal migration of eruptive activity along the volcanic chain suggests the delamination horizon to have propagated south-eastward. The asthenospheric uprise resulting from delamination can account for the partial melting of the lithospheric mantle, and is compatible with the elevated heat flow under the volcanic area (Tari et al. 1999; Demetrescu et al. 2001). Mantle melting within the lower plate, however, is not straightforwardly reconciled with a metasomatic imprint in the source resulting from the westward Miocene subduction. It is conceivable that a portion of initially metasomatised mantle (Fig. 10a) was forced into the delamination-induced void by asthenospheric mantle flow (Fig. 10b), comparable to that modelled by Faccenda et al. (2009) and Andríc et al. (2018).

In contrast, the generation of intraplate magmas in Perşani has been explained by decompression melting of the upwelling asthenosphere itself, possibly associated with a slab-driven convective current (Downes et al. 1995; Seghedi et al. 2004b, 2011). The existence of such upwelling is supported by the presence of a low-velocity and high-attenuation anomaly beneath the area (Russo et al. 2005; Popa et al. 2005; Martin and Wenzel 2006; Ren et al. 2012). The geochemical characteristics described above suggest that the primary melts are derived from an 'OIB-like' asthenospheric mantle source, and have interacted with metasomatic components in the lithosphere as they moved towards the surface. The 'subduction signature' observed in the lavas (Downes et al. 1995) was obtained progressively, rather than inherited from the asthenospheric source. The remarkably small extent of melting required to form the basalts (1-2\%), in accordance with the small volumes of erupted material, is compatible with decompression melting induced by a minor amount of asthenospheric upwelling beneath relatively thin lithosphere (Fig. 10c).

The shoshonites in Southern Harghita are anomalous compared to both the calc-alkaline rocks of the $\mathrm{CGH}$ and the alkali basalts of Perșani. Two of the geochemical features described above provide an explanation for this anomaly. The first is the distinctive enrichment in $\mathrm{K}$ and other LILEs, which indicates that partial melting occurred in a source region highly enriched by slab-derived fluids. The mobilisation of metasomatic agents distinct from those to the northwest may be accounted for by more efficient dehydration of slab remnants under a higher thermal regime (Mason et al. 1998). The second feature is the fractionation of MREEs over HREEs, which implies that melts were derived from depths were garnet was present. This particular signature, in addition to whole-rock elemental and isotopic trends (Mason et al. 1996; Seghedi et al. 2011; Seghedi and Downes 2011; Molnár et al. 2018), indicates that the melts originate from depths greater than the source regions beneath the calc-alkaline segment to the northwest. Given these characteristics and the proximity of Perșani, it is likely that the melting process is related to the same asthenospheric upwelling that generated coeval alkali basalts in Perșani (Fig. 10c), possibly as a result of the inferred slab-driven convective current (e.g. Seghedi et al. 2011). But instead of the shallow asthenosphere, the generation of enriched mafic melts beneath Southern Harghita occurred in a relatively deep lithospheric mantle source.

In summary, East Carpathian post-collisional volcanism appears to have been caused by (1) asthenospheric uprise following the sinking and possibly south-eastward propagating delamination and breakoff of the subducted slab, which induced partial melting of the subduction-modified lithospheric mantle beneath $\mathrm{CGH}$; and (2) decompression melting as a consequence of minor asthenospheric upwelling beneath Perșani. Importantly, the subduction imprints were inherited during post-collisional melting of mantle sources located in the lower plate (distal Europe-Moesia), rather than the overriding plate (Tisza-Dacia). The nature of volcanism and the diversity of source regions involved are demonstrative of the intricate relation between post-collisional magmatism and geodynamic processes.

\section{Conclusions}

We present geochemical data on olivine-hosted melt inclusions and early-formed minerals (spinel, olivine and clinopyroxene) in primitive rock samples from the Neogene-Quaternary East Carpathian volcanic range to probe the nature and origin of post-collisional mantle-derived magmatism.

(1) The mafic melts parental to Călimani calc-alkaline rocks are derived from a lithospheric mantle source metasomatised by sediment-derived melts. Trace-element modelling indicates small-degree (2-12\%) melting of a source to which $\sim 2 \%$ sediment-derived melt was added. Contrasting $\mathrm{Cr} \#$ in $\mathrm{Cr}$-spinel reveal a heterogeneous source region, possibly reflecting relics of previous melt extraction.

(2) Mafic melts beneath Southern Harghita are sourced from the subduction-modified lithospheric mantle. Rare olivine-hosted MIs and abundant Mg-rich clinopyroxene from the K-alkaline (shoshonitic) products of Bixad and Malnaș exhibit 'adakite-like' trace-element signatures, which reflect the presence of hydrous meta- 
somatic phases (amphibole \pm phlogopite) and garnet in the mantle source. Small-degree $(\sim 5 \%)$ melting of a source enriched by sediment-derived melts $(\sim 2 \%)$ and fluids $(\sim 5 \%)$ can effectively generate the parental melt compositions. We infer that metasomatic enrichment of the mantle by subducted slab-derived melts and fluids produced a K- and other LILE-enriched source region, which is spatially heterogeneous.

(3) Na-alkaline melts of Racoș (Perşani) are derived from an 'OIB-like' asthenospheric mantle source by remarkably small degrees (1-2\%) of melting. Increasing enrichment in LILEs over HFSEs and over LREEs in melts during early-stage olivine $\left(\mathrm{Fo}_{90}\right.$ to $\left.\mathrm{Fo}_{82}\right)$ crystallisation suggests that asthenosphere-derived melts consumed hydrous metasomatic components in the overlying, subduction-modified lithosphere. In addition, previously undocumented low-Ca olivines seem to record minor volumes of melts extracted from pyroxenitic source domains, and contrasting $\mathrm{Cr} \#$ in $\mathrm{Cr}$-spinel from Perșani as a whole indicate an intrinsically spatial, rather than temporal, association of mantle source depletion.

An important feature of East Carpathian post-collisional volcanism is that the various lithospheric source regions, significantly modified by subduction-related processes, are located in the lower plate (distal Europe-Moesia), rather than the overriding plate (Tisza-Dacia). Melting appears to have been induced by asthenospheric upwelling following the sinking and possibly south-eastward propagating delamination and breakoff of the subducted slab (Călimani to Southern Harghita). Beneath Perşani, melting resulted from decompression melting as a consequence of minor asthenospheric upwelling, which is likely to be associated with slab steepening beneath Vrancea.

Acknowledgements We gratefully acknowledge Tilly Bouten and Helen de Waard for analytical assistance. We thank Michael C. Rowe and an anonymous reviewer for their constructive comments, and Timothy L. Grove for editorial handling. AJJBG and IKN received funding from the European Research Council (ERC) under the European Union's Horizon 2020 research and innovation programme (Grant Agreement No. 759563). Further financial support was provided by the Netherlands Research Centre for Integrated Solid Earth Science (ISES), through Grant VRF 2.2.3b, and the Romanian Ministry of Research and Innovation, CNCS-UEFISCDI, under project number PN-III-P4-IDPCCF-2016-4-0014, within PNCDI III (to IS).

\section{Compliance with ethical standards}

Conflict of interest The authors declare that they have no conflict of interest.

Open Access This article is licensed under a Creative Commons Attribution 4.0 International License, which permits use, sharing, adaptation, distribution and reproduction in any medium or format, as long as you give appropriate credit to the original author(s) and the source, provide a link to the Creative Commons licence, and indicate if changes were made. The images or other third party material in this article are included in the article's Creative Commons licence, unless indicated otherwise in a credit line to the material. If material is not included in the article's Creative Commons licence and your intended use is not permitted by statutory regulation or exceeds the permitted use, you will need to obtain permission directly from the copyright holder. To view a copy of this licence, visit http://creativecommons.org/licenses/by/4.0/.

\section{References}

Aldanmaz E, Pearce JA, Thirlwall MF, Mitchell JG (2000) Petrogenetic evolution of late Cenozoic, post-collision volcanism in western Anatolia, Turkey. J Volcanol Geotherm Res 102:67-95. https:// doi.org/10.1016/S0377-0273(00)00182-7

Aldanmaz E, Köprübaşi N, Gürer ÖF et al (2006) Geochemical constraints on the Cenozoic, OIB-type alkaline volcanic rocks of NW Turkey: implications for mantle sources and melting processes. Lithos 86:50-76. https://doi.org/10.1016/j.lithos.2005.04.003

Allan JF, Sack RO, Batiza R (1988) Cr-rich spinels as petrogenetic indicators: MORB-type lavas from the Lamont seamount chain, eastern Pacific. Am Mineral 73:741-753

Andríc N, Vogt K, Matenco L et al (2018) Variability of orogenic magmatism during Mediterranean-style continental collisions: a numerical modelling approach. Gondwana Res 56:119-134. https://doi.org/10.1016/j.gr.2017.12.007

Arai S (1994) Characterization of spinel peridotites by olivine-spinel compositional relationships: review and interpretation. Chem Geol 113:191-204. https://doi.org/10.1016/0009-2541(94)90066 $-3$

Balla Z (1987) Tertiary paleomagnetic data for the Carpathian-Pannonian region in the light of Miocene rotation kinematics. Tectonophysics 139:67-98. https://doi.org/10.1016/0040-1951(87)90198 $-3$

Barry TL, Saunders AD, Kempton PD et al (2003) Petrogenesis of Cenozoic basalts from Mongolia: evidence for the role of asthenospheric versus metasomatized lithospheric mantle Sources. J Petrol 44:55-91. https://doi.org/10.1093/petrology/44.1.55

Bertotti G, Matenco L, Cloetingh S (2003) Vertical movements in and around the south-east Carpathian foredeep: lithospheric memory and stress field control. Terra Nova 15:299-305. https://doi.org/ 10.1046/j.1365-3121.2003.00499.x

Bird P (1979) Continental delamination and the Colorado Plateau. J Geophys Res Solid Earth 84:7561-7571. https://doi.org/10.1029/ JB084iB13p07561

Blundy J, Wood B (2003) Partitioning of trace elements between crystals and melts. Earth Planet Sci Lett 210:383-397. https://doi. org/10.1016/S0012-821X(03)00129-8

Blundy JD, Robinson JAC, Wood BJ (1998) Heavy REE are compatible in clinopyroxene on the spinel lherzolite solidus. Earth Planet Sci Lett 160:493-504. https://doi.org/10.1016/S0012 $-821 \mathrm{X}(98) 00106-\mathrm{X}$

Boudier F (1991) Olivine xenocrysts in picritic magmas. Contrib Mineral Petrol 109:114-123. https://doi.org/10.1007/BF00687204

Castillo PR (2008) Origin of the adakite-high-Nb basalt association and its implications for postsubduction magmatism in Baja California, Mexico. Bull Geol Soc Am 120:451-462. https://doi. org/10.1130/B26166.1

Castillo PR (2012) Adakite petrogenesis. Lithos 134-135:304-316. https://doi.org/10.1016/j.lithos.2011.09.013 
Castillo PR, Janney PE, Solidum RU (1999) Petrology and geochemistry of Camiguin Island, southern Philippines: insights to the source of adakites and other lavas in a complex arc setting. Contrib Mineral Petrol 134:33-51. https://doi.org/10.1007/s0041 00050467

Cawthorn RG, Collerson K (1974) The recalculation of pyroxene end-member parameters and the estimation of ferrous and ferric iron content from electron microprobe analyses. Am Mineral 59:1203-1208

Chalot-Prat F, Girbacea R (2000) Partial delamination of continental mantle lithosphere, uplift-related crust-mantle decoupling, volcanism and basin formation: a new model for the PlioceneQuaternary evolution of the southern East-Carpathians, Romania. Tectonophysics 327:83-107. https://doi.org/10.1016/S0040 -1951(00)00155-4

Ciulavu D, Dinu C, Szakács A, Dordea D (2000) Neogene kinematics of the Transylvanian basin (Romania). Am Assoc Pet Geol Bull 84:1589-1615. https://doi.org/10.1306/8626BF0B-173B11D7-8645000102C1865D

Cloetingh SAPL, Burov E, Matenco L et al (2004) Thermo-mechanical controls on the mode of continental collision in the SE Carpathians (Romania). Earth Planet Sci Lett 218:57-76. https://doi. org/10.1016/S0012-821X(03)00645-9

Csontos L (1995) Tertiary tectonic evolution of the Intra-Carpathian area: a review. Acta Vulcanol 7:1-13

Dalpé C, Baker DR (2000) Experimental investigation of large-ionlithophile-element-, high-field-strength-element- and rare-earthelement-partitioning between calcic amphibole and basaltic melt: the effects of pressure and oxygen fugacity. Contrib Mineral Petrol 140:233-250. https://doi.org/10.1007/s004100000181

Danyushevsky LV, Sokolov S, Falloon TJ (2002) Melt inclusions in olivine phenocrysts: using diffusive re-equilibration to determine the cooling history of a crystal, with implications for the origin of olivine-phyric volcanic rocks. J Petrol 43:1651-1671. https:// doi.org/10.1093/petrology/43.9.1651

de Hoog JCM, Mason PRD, van Bergen MJ (2001) Sulfur and chalcophile elements in subduction zones: constraints from a laser ablation ICP-MS study of melt inclusions from Galunggung volcano, Indonesia. Geochim Cosmochim Acta 65:3147-3164. https://doi. org/10.1016/S0016-7037(01)00634-2

de Hoog JCM, Gall L, Cornell DH (2010) Trace-element geochemistry of mantle olivine and application to mantle petrogenesis and geothermobarometry. Chem Geol 270:196-215. https://doi. org/10.1016/j.chemgeo.2009.11.017

Defant MJ, Drummond MS (1990) Derivation of some modern arc magmas by melting of young subducted lithosphere. Nature 347:662-665. https://doi.org/10.1038/347662a0

Demetrescu C, Nielsen SB, Ene M et al (2001) Lithosphere thermal structure and evolution of the Transylvanian depression-insights from new geothermal measurements and modelling results. Phys Earth Planet Inter 126:249-267. https://doi.org/10.1016/S0031 -9201(01)00259-X

Dick HJB, Bullen T (1984) Chromian spinel as a petrogenetic indicator in abyssal and alpine-type peridotites and spatially associated lavas. Contrib Mineral Petrol 86:54-76. https://doi.org/10.1007/ BF00373711

Downes H, Seghedi I, Szakács A et al (1995) Petrology and geochemistry of late Tertiary/Quaternary mafic alkaline volcanism in Romania. Lithos 35:65-81. https://doi.org/10.1016/00244937(95)91152-Y

Elliott TR, Plank T, Zindler A et al (1997) Element transport from slab to volcanic front at the Mariana arc. J Geophys Res Solid Earth 102:14991-15019. https://doi.org/10.1029/97JB00788

Embey-Isztin A, Dobosi G (1995) Mantle source characteristics for Miocene-Pleistocene alkali basalts, Carpathian-Pannonian
Region: a review of trace elements and isotopic composition. Acta Vulcanol 7:155-166

Embey-Isztin A, Downes H, James DE et al (1993) The petrogenesis of Pliocene alkaline volcanic rocks from the Pannonian Basin, eastern Central Europe. J Petrol 34:317-343. https://doi.org/10.1093/ petrology/34.2.317

Faccenda M, Minelli G, Gerya TV (2009) Coupled and decoupled regimes of continental collision: numerical modeling. Earth Planet Sci Lett 278:337-349. https://doi.org/10.1016/J. EPSL.2008.12.021

Faccini B, Rizzo AL, Bonadiman C et al (2020) Subduction-related melt refertilisation and alkaline metasomatism in the Eastern Transylvanian Basin lithospheric mantle: evidence from mineral chemistry and noble gases in fluid inclusions. Lithos 364365:105516. https://doi.org/10.1016/j.lithos.2020.105516

Falus G, Tommasi A, Ingrin J, Szabó C (2008) Deformation and seismic anisotropy of the lithospheric mantle in the southeastern Carpathians inferred from the study of mantle xenoliths. Earth Planet Sci Lett 272:50-64. https://doi.org/10.1016/J.EPSL.2008.04.035

Fedele L, Seghedi I, Chung S-L et al (2016) Post-collisional magmatism in the Late Miocene Rodna-Bârgău district (East Carpathians, Romania): geochemical constraints and petrogenetic models. Lithos 266-267:367-382. https://doi.org/10.1016/j.litho s.2016.10.015

Fillerup MA, Knapp JH, Knapp CC, Raileanu V (2010) Mantle earthquakes in the absence of subduction? Continental delamination in the Romanian Carpathians. Lithosphere 2:333-340. https:// doi.org/10.1130/L102.1

Francis D, Ludden J (1995) The signature of amphibole in mafic alkaline lavas, a study in the Northern Canadian Cordillera. J Petrol 36:1171-1191. https://doi.org/10.1093/petrology/36.5.1171

Furman T, Graham D (1999) Erosion of lithospheric mantle beneath the East African Rift system: geochemical evidence from the Kivu volcanic province. Lithos 48:237-262. https://doi.org/10.1016/ S0419-0254(99)80014-7

Gaetani GA, Kent AJR, Grove TL et al (2003) Mineral/melt partitioning of trace elements during hydrous peridotite partial melting. Contrib Mineral Petrol 145:391-405. https://doi.org/10.1007/ s00410-003-0447-0

Gągała Ł, Vergés J, Saura E et al (2012) Architecture and orogenic evolution of the northeastern Outer Carpathians from cross-section balancing and forward modeling. Tectonophysics 532-535:223241. https://doi.org/10.1016/j.tecto.2012.02.014

Garzanti E, Radeff G, Malusà MG (2018) Slab breakoff: a critical appraisal of a geological theory as applied in space and time. Earth Sci Rev 177:303-319. https://doi.org/10.1016/j.earsc irev.2017.11.012

Gavrilenko M, Herzberg C, Vidito C et al (2016) A calcium-in-olivine geohygrometer and its application to subduction zone magmatism. J Petrol 57:1811-1832. https://doi.org/10.1093/petrology/ egw062

Gesch DB, Verdin KL, Greenlee SK (1999) New land surface digital elevation model covers the Earth. EOS Trans Am Geophys Union 80:69. https://doi.org/10.1029/99EO00050

Gibson SA, Geist D (2010) Geochemical and geophysical estimates of lithospheric thickness variation beneath Galápagos. Earth Planet Sci Lett 300:275-286. https://doi.org/10.1016/j.eps1.2010.10.002

Gîrbacea R, Frisch W (1998) Slab in the wrong place: lower lithospheric mantle delamination in the last stage of the Eastern Carpathian subduction retreat. Geology 26:611. https ://doi.org/10.1130/0091-7613(1998)026\%3c0611:SITWP $\mathrm{L} \% 3 \mathrm{e} 2.3 . \mathrm{CO} ; 2$

Gîrbacea R, Frisch W, Linzer H-G (1998) Post-orogenic uplift-induced extension: a kinematic model for the Pliocene to Recent tectonic 
evolution of the Eastern Carpathians (Romania). Geol Carpathica 49:315-327

Göğüş OH, Pysklywec RN, Faccenna C (2016) Postcollisional lithospheric evolution of the Southeast Carpathians: comparison of geodynamical models and observations. Tectonics 35:12051224. https://doi.org/10.1002/2015TC004096

Gvirtzman Z (2002) Partial detachment of a lithospheric root under the southeast Carpathians: toward a better definition of the detachment concept. Geology 30:51. https://doi.org/10.1130/00917613(2002)030\%3c0051:PDOALR\%3e2.0.CO;2

Halter WE, Pettke T, Heinrich CA, Rothen-Rutishauser B (2002) Major to trace element analysis of melt inclusions by laser-ablation ICPMS: methods of quantification. Chem Geol 183:63-86. https:// doi.org/10.1016/S0009-2541(01)00372-2

Harangi S, Sági T, Seghedi I, Ntaflos T (2013) Origin of basaltic magmas of Perşani volcanic field, Romania: a combined whole rock and mineral scale investigation. Lithos 180-181:43-57. https:// doi.org/10.1016/j.lithos.2013.08.025

Harangi S, Jankovics MÉ, Sági T et al (2015) Origin and geodynamic relationships of the Late Miocene to Quaternary alkaline basalt volcanism in the Pannonian basin, eastern-central Europe. Int J Earth Sci 104:2007-2032. https://doi.org/10.1007/s0053 1-014-1105-7

Hart SR, Dunn T (1993) Experimental cpx/melt partitioning of 24 trace elements. Contrib Mineral Petrol 113:1-8. https://doi. org/10.1007/BF00320827

Hauri EH, Wagner TP, Grove TL (1994) Experimental and natural partitioning of $\mathrm{Th}, \mathrm{U}, \mathrm{Pb}$ and other trace elements between garnet, clinopyroxene and basaltic melts. Chem Geol 117:149-166. https ://doi.org/10.1016/0009-2541(94)90126-0

Hawkesworth CJ, Turner SP, McDermott F et al (1997) U-Th isotopes in arc magmas: implications for element transfer from the subducted crust. Science 276:551-555. https://doi.org/10.1126/scien ce.276.5312.551

Herzberg C (2011) Identification of source lithology in the Hawaiian and Canary Islands: implications for origins. J Petrol 52:113146. https://doi.org/10.1093/petrology/egq075

Herzberg C, Asimow PD, Ionov DA et al (2013) Nickel and helium evidence for melt above the core-mantle boundary. Nature 493:393-397. https://doi.org/10.1038/nature11771

Hirano N, Yamamoto J, Kagi H, Ishii T (2004) Young, olivine xenocryst-bearing alkali-basalt from the oceanward slope of the Japan Trench. Contrib Mineral Petrol 148:47-54. https://doi. org/10.1007/s00410-004-0593-z

Hole MJ (2018) Mineralogical and geochemical evidence for polybaric fractional crystallization of continental flood basalts and implications for identification of peridotite and pyroxenite source lithologies. Earth Sci Rev 176:51-67. https://doi.org/10.1016/j. earscirev.2017.09.014

Horváth F, Bada G, Szafián P et al (2006) Formation and deformation of the Pannonian Basin: constraints from observational data. Geol Soc Lond Mem 32:191-206. https://doi.org/10.1144/GSL. MEM.2006.032.01.11

Houseman GA, Gemmer L (2007) Intra-orogenic extension driven by gravitational instability: carpathian-Pannonian orogeny. Geology 35:1135. https://doi.org/10.1130/G23993A.1

Ionov DA, Hofmann AW (1995) Nb-Ta-rich mantle amphiboles and micas: implications for subduction-related metasomatic trace element fractionations. Earth Planet Sci Lett 131:341-356. https:// doi.org/10.1016/0012-821X(95)00037-D

Ismail-Zadeh A, Matenco L, Radulian M et al (2012) Geodynamics and intermediate-depth seismicity in Vrancea (the south-eastern Carpathians): current state-of-the art. Tectonophysics 530-531:5079. https://doi.org/10.1016/J.TECTO.2012.01.016

Jankovics MÉ, Sági T, Astbury RL et al (2019) Olivine major and trace element compositions coupled with spinel chemistry to unravel the magmatic systems feeding monogenetic basaltic volcanoes. J Volcanol Geotherm Res 369:203-223. https://doi.org/10.1016/j. jvolgeores.2018.11.027

Jaques AL, Green DH (1980) Anhydrous melting of peridotite at $0-15 \mathrm{~kb}$ pressure and the genesis of tholeiitic basalts. Contrib Mineral Petrol 73:287-310. https://doi.org/10.1007/BF00381447

Jarosewich E, Nelen JA, Norberg JA (1980) Reference samples for electron microprobe analysis. Geostand Newsl 4:43-47. https:// doi.org/10.1111/j.1751-908X.1980.tb00273.x

Jochum KP, Stoll B (2008) Reference materials for elemental and isotopic analyses by LA-(MC)-ICP-MS: Successes and outstanding needs. In: Sylvester P (ed) Laser ablation ICP-MS in the earth sciences: current practices and outstanding issues. Mineralogical Association of Canada Short Course Series, Toronto, pp 147-168

Johnson KTM (1998) Experimental determination of partition coefficients for rare earth and high-field-strength elements between clinopyroxene, garnet, and basaltic melt at high pressures. Contrib Mineral Petrol 133:60-68. https://doi.org/10.1007/s0041 00050437

Johnson MC, Plank T (1999) Dehydration and melting experiments constrain the fate of subducted sediments. Geochem Geophys Geosyst. https://doi.org/10.1029/1999GC000014

Kamenetsky VS, Crawford AJ, Meffre S (2001) Factors controlling chemistry of magmatic spinel: an empirical study of associated olivine, Cr-spinel and melt inclusions from primitive rocks. J Petrol 42:655-671. https://doi.org/10.1093/petrology/42.4.655

Kent AJR, Elliott TR (2002) Melt inclusions from Marianas arc lavas: implications for the composition and formation of island arc margins. Chem Geol 183:263-286. https://doi.org/10.1016/S0009 -2541(01)00378-3

Kepezhinskas PK, Defant MJ, Drummond MS (1995) Na metasomatism in the island-arc mantle by slab melt-peridotite interaction: evidence from mantle xenoliths in the North Kamchatka arc. J Petrol 36:1505-1527. https://doi.org/10.1093/oxfordjournals. petrology.a037263

Kessel R, Schmidt MW, Ulmer P, Pettke T (2005) Trace element signature of subduction-zone fluids, melts and supercritical liquids at 120-180 km depth. Nature 437:724-727. https://doi.org/10.1038/ nature 03971

Kinzler RJ, Grove TL (1992) Primary magmas of mid-ocean ridge basalts 1. Experiments and methods. J Geophys Res 97:68856906. https://doi.org/10.1029/91JB02840

Knapp JH, Knapp CC, Raileanu V et al (2005) Crustal constraints on the origin of mantle seismicity in the Vrancea Zone, Romania: the case for active continental lithospheric delamination. Tectonophysics 410:311-323. https://doi.org/10.1016/J.TECTO .2005 .02 .020

Koulakov I, Zaharia B, Enescu B et al (2010) Delamination or slab detachment beneath Vrancea? New arguments from local earthquake tomography. Geochem Geophys Geosyst. https://doi. org/10.1029/2009GC002811

Kovacs M, Seghedi I, Yamamoto M et al (2017) Miocene volcanism in the Oaş-Gutâi volcanic zone, Eastern Carpathians, Romania: relationship to geodynamic processes in the Transcarpathian Basin. Lithos 294-295:304-318. https://doi.org/10.1016/j.litho s.2017.09.027

La Flèche MR, Camiré G, Jenner GA (1998) Geochemistry of postAcadian, Carboniferous continental intraplate basalts from the Maritimes Basin, Magdalen Islands, Québec, Canada. Chem Geol 148:115-136. https://doi.org/10.1016/S0009 -2541(98)00002-3

Langmuir CH, Klein EM, Plank T (1992) Petrological systematics of mid-ocean ridge basalts: constraints on melt generation beneath ocean ridges. In: Mantle flow and melt generation at mid-ocean ridges. Geophysical Monograph Series, vol 71. pp 183-280 
LaTourrette T, Hervig RL, Holloway JR (1995) Trace element partitioning between amphibole, phlogopite, and basanite melt. Earth Planet Sci Lett 135:13-30. https://doi.org/10.1016/0012821X(95)00146-4

Laubier M, Grove TL, Langmuir CH (2014) Trace element mineral/ melt partitioning for basaltic and basaltic andesitic melts: an experimental and laser ICP-MS study with application to the oxidation state of mantle source regions. Earth Planet Sci Lett 392:265-278. https://doi.org/10.1016/j.eps1.2014.01.053

Laumonier M, Karakas O, Bachmann O et al (2019) Evidence for a persistent magma reservoir with large melt content beneath an apparently extinct volcano. Earth Planet Sci Lett 521:79-90. https://doi.org/10.1016/J.EPSL.2019.06.004

Le Bas MJ, Le Maitre RW, Streckeisen A, Zanettin B (1986) A chemical classification of volcanic rocks based on the total alkali-silica diagram. J Petrol 27:745-750. https://doi.org/10.1093/petro $\log / 27.3 .745$

Lexa J, Seghedi I, Németh K et al (2010) Neogene-quaternary volcanic forms in the Carpathian-Pannonian region: a review. Cent Eur J Geosci 2:207-270. https://doi.org/10.2478/v10085-010-0024-5

Ma GS-K, Malpas J, Xenophontos C, Chan GH-N (2011) Petrogenesis of latest Miocene-Quaternary continental intraplate volcanism along the northern Dead Sea Fault System (Al Ghab-Homs volcanic field), western Syria: evidence for lithosphere-asthenosphere interaction. J Petrol 52:401-430. https://doi.org/10.1093/ petrology/egq085

Macpherson CG, Dreher ST, Thirlwall MF (2006) Adakites without slab melting: high pressure differentiation of island arc magma, Mindanao, the Philippines. Earth Planet Sci Lett 243:581-593. https://doi.org/10.1016/j.eps1.2005.12.034

Martin M, Wenzel F (2006) High-resolution teleseismic body wave tomography beneath SE-Romania-II. Imaging of a slab detachment scenario. Geophys J Int 164:579-595. https://doi. org/10.1111/j.1365-246X.2006.02884.x

Mason PRD (1995) Petrogenesis of subduction-related magmatic rocks from the East Carpathians, Romania. PhD Thesis, University of London, Birkbeck College, London

Mason PRD, Downes H, Seghedi I et al (1995) Low-pressure evolution of magmas from the Calimani, Gurghiu and Harghita Mountains, East Carpathians. Acta Vulcanol 7:43-52

Mason PRD, Downes H, Thirlwall MF et al (1996) Crustal assimilation as a major petrogenetic process in the East Carpathian Neogene and Quaternary continental margin arc, Romania. J Petrol 37:927-959. https://doi.org/10.1093/petrology/37.4.927

Mason PRD, Seghedi I, Szakács A, Downes H (1998) Magmatic constraints on geodynamic models of subduction in the East Carpathians, Romania. Tectonophysics 297:157-176. https://doi. org/10.1016/S0040-1951(98)00167-X

Mason PRD, Nikogosian IK, van Bergen MJ (2008) Major and trace element analysis of melt inclusions by laser ablation ICP-MS. In: Laser ablation ICP-MS in the earth sciences: current practices and outstanding issues: mineralogical association of Canada short course series, vol 40. pp 219-240

Matenco L, Bertotti G (2000) Tertiary tectonic evolution of the external East Carpathians (Romania). Tectonophysics 316:255-286. https ://doi.org/10.1016/S0040-1951(99)00261-9

Matenco L, Krézsek C, Merten S et al (2010) Characteristics of collisional orogens with low topographic build-up: an example from the Carpathians. Terra Nova 22:155-165. https://doi.org/10.111 1/j.1365-3121.2010.00931.x

Matsukage KN, Kubo K (2004) Chromian spinel during melting experiments of dry peridotite (KLB-1) at 1.0-2.5 GPa. Am Mineral 88:1271-1278. https://doi.org/10.2138/am-2003-8-909

McDonough WF, Sun S-S (1995) The composition of the Earth. Chem Geol 120:223-253. https://doi.org/10.1016/0009-2541(94)00140 $-4$
Miyashiro A (1978) Nature of alkalic volcanic rock series. Contrib Mineral Petrol 66:91-104. https://doi.org/10.1007/BF00376089

Molnár K, Harangi S, Lukács R et al (2018) The onset of the volcanism in the Ciomadul volcanic dome complex (Eastern Carpathians): eruption chronology and magma type variation. J Volcanol Geotherm Res 354:39-56. https://doi.org/10.1016/j.jvolgeores 2018.01.025

Molnár K, Lukács R, Dunkl I et al (2019) Episodes of dormancy and eruption of the Late Pleistocene Ciomadul volcanic complex (Eastern Carpathians, Romania) constrained by zircon geochronology. J Volcanol Geotherm Res 373:133-147. https://doi. org/10.1016/j.jvolgeores.2019.01.025

Morimoto N (1988) Nomenclature of pyroxenes. Am Mineral 73:11231133. https://doi.org/10.1007/BF01226262

Nemcok M, Pospisil L, Lexa J, Donelick RA (1998) Tertiary subduction and slab break-off model of the Carpathian-Pannonian region. Tectonophysics 295:307-340. https://doi.org/10.1016/ S0040-1951(98)00092-4

Nikogosian IK, van Bergen MJ (2010) Heterogeneous mantle sources of potassium-rich magmas in central-southern Italy: melt inclusion evidence from Roccamonfina and Ernici (Mid Latina Valley). J Volcanol Geotherm Res 197:279-302. https://doi. org/10.1016/j.jvolgeores.2010.06.014

Nikogosian IK, Ersoy Ö, Whitehouse MJ et al (2016) Multiple subduction imprints in the mantle below Italy detected in a single lava flow. Earth Planet Sci Lett 449:12-19. https://doi.org/10.1016/j. eps1.2016.05.033

Nikogosian IK, Bracco Gartner AJJ, van Bergen MJ et al (2018) Mantle sources of recent Anatolian intraplate magmatism: a regional plume or local tectonic origin? Tectonics 37:4535-4566. https ://doi.org/10.1029/2018TC005219

Niu Y (2017) Slab breakoff: a causal mechanism or pure convenience? Sci Bull 62:456-461. https://doi.org/10.1016/j.scib.2017.03.015

Niu Y, Wilson M, Humphreys ER, O'Hara MJ (2011) The origin of intra-plate ocean island basalts (OIB): the lid effect and its geodynamic implications. J Petrol 52:1443-1468. https://doi. org/10.1093/petrology/egr030

Panaiotu CG, Pécskay Z, Hambach U et al (2004) Short-lived quaternary volcanism in the Persani Mountains (Romania) revealed by combined K-Ar and paleomagnetic data. Geol Carpathica 55:333-339

Panaiotu CG, Jicha BR, Singer BS et al (2013) 40Ar/39Ar chronology and paleomagnetism of Quaternary basaltic lavas from the Perşani Mountains (East Carpathians). Phys Earth Planet Inter 221:1-14. https://doi.org/10.1016/j.pepi.2013.06.007

Pearce JA, Peate DW (1995) Tectonic implications of the composition of volcanic arc magmas. Annu Rev Earth Planet Sci 23:251-285. https://doi.org/10.1146/annurev.ea.23.050195.001343

Pearce NJG, Perkins WT, Westgate JA et al (1997) A compilation of new and published major and trace element data for NIST SRM 610 and NIST SRM 612 glass reference materials. Geostand Newsl 21:115-144. https://doi.org/10.1111/j.1751-908X.1997. tb00538.x

Peccerillo A (2017) Cenozoic volcanism in the Tyrrhenian Sea region, 2nd edn. Springer International Publishing AG, Berlin

Peccerillo A, Taylor SR (1976) Geochemistry of Eocene calc-alkaline volcanic rocks from the Kastamonu area, Northern Turkey. Contrib Mineral Petrol 58:63-81. https://doi.org/10.1007/BF003 84745

Pécskay Z, Edelstein O, Seghedi I et al (1995) K-Ar datings of Neogene-Quaternary calc-alkaline volcanic rocks in Romania. Acta Vulcanol 7:53-61

Pécskay Z, Lexa J, Szakács A et al (2006) Geochronology of Neogene magmatism in the Carpathian arc and intra-Carpathian area. Geol Carpathica 57:511-530 
Pécskay Z, Seghedi I, Kovacs M et al (2009) Geochronology of the Neogene calc-alkaline intrusive magmatism in the "Subvolcanic Zone" of the Eastern Carpathians (Romania). Geol Carpathica 60:181-190. https://doi.org/10.2478/v10096-009-0012-5

Peltz S, Vajdea E, Balogh K, Pécskay Z (1987) Contributions to the geochronological study of the volcanic processes in the Calimani and Harghita Mountains (East Carpathians, Romania). Dări Seamă ale Şedinţelor Institutul Geol şi Geofiz 72-73:323-338

Pilet S, Baker MB, Müntener O, Stolper EM (2011) Monte Carlo simulations of metasomatic enrichment in the lithosphere and implications for the source of alkaline basalts. J Petrol 52:1415-1442. https://doi.org/10.1093/petrology/egr007

Plank T (2005) Constraints from Thorium/Lanthanum on sediment recycling at subduction zones and the evolution of the continents. J Petrol 46:921-944. https://doi.org/10.1093/petrology/egi005

Plank T (2014) The chemical composition of subducting sediments. In: Holland HD, Turekian KK (eds) Treatise on geochemistry, 2nd edn. Elsevier, Amsterdam, pp 607-629

Plank T, Langmuir CH (1998) The chemical composition of subducting sediment and its consequences for the crust and mantle. Chem Geol 145:325-394. https://doi.org/10.1016/S0009 -2541(97)00150-2

Popa M, Radulian M, Grecu B et al (2005) Attenuation in Southeastern Carpathians area: result of upper mantle inhomogeneity. Tectonophysics 410:235-249. https://doi.org/10.1016/j.tecto .2004 .12 .037

Popa M, Radulian M, Szakács A et al (2012) New seismic and tomography data in the southern part of the Harghita Mountains (Romania, Southeastern Carpathians): connection with recent volcanic activity. Pure Appl Geophys 169:1557-1573. https:// doi.org/10.1007/s00024-011-0428-6

Prouteau G, Scaillet B, Pichavant M, Maury R (2001) Evidence for mantle metasomatism by hydrous silicic melts derived from subducted oceanic crust. Nature 410:197-200. https://doi. org/10.1038/35065583

Rădulescu DP, Săndulescu M (1973) The plate-tectonics concept and the geological structure of the Carpathians. Tectonophysics 16:155-161. https://doi.org/10.1016/0040-1951(73)90010-3

Rapp RP, Shimizu N, Norman MD, Applegate GS (1999) Reaction between slab-derived melts and peridotite in the mantle wedge: experimental constraints at 3.8 GPa. Chem Geol 160:335-356. https://doi.org/10.1016/S0009-2541(99)00106-0

Ren Y, Stuart GW, Houseman GA et al (2012) Upper mantle structures beneath the Carpathian-Pannonian region: implications for the geodynamics of continental collision. Earth Planet Sci Lett 349-350:139-152. https://doi.org/10.1016/j.epsl.2012.06.037

Roedder E (1984) Fluid inclusions. In: Ribbe PH (ed) Reviews in mineralogy. Mineralogical Society of America, Washington, DC, p 620

Rosenbaum G, Gasparon M, Lucente FP et al (2008) Kinematics of slab tear faults during subduction segmentation and implications for Italian magmatism. Tectonics. https://doi.org/10.1029/2007T C002143

Royden LH (1988) Late Cenozoic tectonics of the Pannonian Basin system. In: Royden LH, Horváth F (eds) The Pannonian Basin: a study in basin evolution. American Association of Petroleum Geologists (AAPG), Tulsa, pp 27-48

Russo RM, Mocanu V, Radulian M et al (2005) Seismic attenuation in the Carpathian bend zone and surroundings. Earth Planet Sci Lett 237:695-709. https://doi.org/10.1016/j.epsl.2005.06.046

Săndulescu M (1988) Cenozoic tectonic history of the Carpathians. In: Royden LH, Horváth F (eds) The Pannonian basin: a study in basin evolution. American Association of Petroleum Geologists (AAPG), Tulsa, p 394
Schiano P, Clocchiatti R, Shimizu N et al (1995) Hydrous, silica-rich melts in the sub-arc mantle and their relationship with erupted arc lavas. Nature 377:595-600. https://doi.org/10.1038/377595a0

Schmid SM, Fügenschuh B, Kounov A et al (2020) Tectonic units of the Alpine collision zone between Eastern Alps and western Turkey. Gondwana Res 78:308-374. https://doi.org/10.1016/j. gr.2019.07.005

Seghedi I, Downes H (2011) Geochemistry and tectonic development of Cenozoic magmatism in the Carpathian-Pannonian region. Gondwana Res 20:655-672. https://doi.org/10.1016/J. GR.2011.06.009

Seghedi I, Szakács A, Mason PRD (1995) Petrogenesis and magmatic evolution in the East Carpathian Neogene volcanic arc (Romania). Acta Vulcanol 7:135-143

Seghedi I, Balintoni I, Szakács A (1998) Interplay of tectonics and Neogene post-collisional magmatism in the Intracarpathian region. Lithos 45:483-497. https://doi.org/10.1016/S0024 $-4937(98) 00046-2$

Seghedi I, Downes H, Szakács A et al (2004a) Neogene-Quaternary magmatism and geodynamics in the Carpathian-Pannonian region: a synthesis. Lithos 72:117-146. https://doi.org/10.1016/j. lithos.2003.08.006

Seghedi I, Downes H, Vaselli O et al (2004b) Post-collisional Tertiary-Quaternary mafic alkalic magmatism in the CarpathianPannonian region: a review. Tectonophysics 393:43-62. https:// doi.org/10.1016/J.TECTO.2004.07.051

Seghedi I, Szakács A, Pécskay Z, Mason PRD (2005) Eruptive history and age of magmatic processes in the Calimani volcanic structure (Romania). Geol Carphatica 56:67-75

Seghedi I, Maţenco L, Downes H et al (2011) Tectonic significance of changes in post-subduction Pliocene-Quaternary magmatism in the south east part of the Carpathian-Pannonian Region. Tectonophysics 502:146-157. https://doi.org/10.1016/j.tecto .2009 .12 .003

Seghedi I, Popa R-G, Panaiotu CG et al (2016) Short-lived eruptive episodes during the construction of a Na-alkalic basaltic field (Perşani Mountains, SE Transylvania, Romania). Bull Volcanol 78:69. https://doi.org/10.1007/s00445-016-1063-y

Seghedi I, Besutiu L, Mirea V et al (2019) Tectono-magmatic characteristics of post-collisional magmatism: case study East Carpathians, Călimani-Gurghiu-Harghita volcanic range. Phys Earth Planet Inter 293:106270. https://doi.org/10.1016/J. PEPI.2019.106270

Sen C, Dunn T (1995) Experimental modal metasomatism of a spinel lherzolite and the production of amphibole-bearing peridotite. Contrib Mineral Petrol 119:422-432. https://doi.org/10.1007/ BF00286939

Shaw DM (1970) Trace element fractionation during anatexis. Geochim Cosmochim Acta 34:237-243. https://doi. org/10.1016/0016-7037(70)90009-8

Smith DR, Leeman WP (2005) Chromian spinel-olivine phase chemistry and the origin of primitive basalts of the southern Washington Cascades. J Volcanol Geotherm Res 140:49-66. https ://doi.org/10.1016/j.jvolgeores.2004.07.015

Sobolev AV (1996) Melt inclusions in minerals as a source of principle petrological information. Petrology 4:209-220

Sobolev AV, Migdisov AA, Portnyagin MV (1996) Incompatible element partitioning between clinopyroxene and basalt liquid revealed by the study of melt inclusions in minerals from Troodos lavas, Cyprus. Petrology 4:307-317

Sobolev AV, Hofmann AW, Kuzmin DV et al (2007) The amount of recycled crust in sources of mantle-derived melts. Science 316:412-417. https://doi.org/10.1126/science.1138113

Sperner B, Lorenz F, Bonjer K et al (2001) Slab break-off-abrupt cut or gradual detachment? New insights from the Vrancea 
Region (SE Carpathians, Romania). Terra Nova 13:172-179. https://doi.org/10.1046/j.1365-3121.2001.00335.x

Sperner B, Ioane D, Lillie RJ (2004) Slab behaviour and its surface expression: new insights from gravity modelling in the SE-Carpathians. Tectonophysics 382:51-84. https://doi.org/10.1016/J. TECTO.2003.12.008

Stevens RE (1944) Composition of some chromites of the Western Hemisphere. Am Mineral 29:1-34

Sun S-S, McDonough WF (1989) Chemical and isotopic systematics of oceanic basalts: Implications for mantle composition and processes. In: Saunders AD, Norry MJ (eds) Magmatism in the ocean basins. Geological Society Special Publication, pp 313-345

Suzuki T, Hirata T, Yokoyama TD et al (2012) Pressure effect on element partitioning between minerals and silicate melt: melting experiments on basalt up to $20 \mathrm{GPa}$. Phys Earth Planet Inter 208-209:59-73. https://doi.org/10.1016/j.pepi.2012.07.008

Szabó C, Falus G, Zajacz Z et al (2004) Composition and evolution of lithosphere beneath the Carpathian-Pannonian Region: a review. Tectonophysics 393:119-137. https://doi.org/10.1016/j. tecto.2004.07.031

Szakács A, Seghedi I (1995) The Calimani-Gurghiu-Harghita volcanic chain, East Carpathians, Romania: volcanological features. Acta Vulcanol 7:145-153

Szakács A, Seghedi I, Pécskay Z (1993) Peculiarities of South Harghita Mts as a terminal segment of the Carpathian Neogene to Quaternary volcanic chain. Rev Roum Géologie Géophysique Géographie 37:21-36

Szakács A, Ioane D, Seghedi I et al (1997) Rates of migration of volcanic activity and magma output along the Calimani-GurghiuHarghita volcanic range, East Carpathians, Romania. Przegląd Geol 45:1106

Szakács A, Seghedi I, Pécskay Z, Mirea V (2015) Eruptive history of a low-frequency and low-output rate Pleistocene volcano, Ciomadul, South Harghita Mts., Romania. Bull Volcanol 77:12. https://doi.org/10.1007/s00445-014-0894-7

Szakács A, Pécskay Z, Gál Á (2018) Patterns and trends of timespace evolution of Neogene volcanism in the Carpathian-Pannonian region: a review. Acta Geod Geophys 53:347-367. https ://doi.org/10.1007/s40328-018-0230-3
Tari G, Dövényi P, Dunkl I et al (1999) Lithospheric structure of the Pannonian basin derived from seismic, gravity and geothermal data. Geol Soc Lond Spec Publ 156:215-250. https://doi. org/10.1144/GSL.SP.1999.156.01.12

Tommasini S, Heumann A, Avanzinelli R, Francalanci L (2007) The fate of high-angle dipping slabs in the subduction factory: an integrated trace element and radiogenic isotope $(\mathrm{U}, \mathrm{Th}, \mathrm{Sr}, \mathrm{Nd}$, $\mathrm{Pb}$ ) study of Stromboli Volcano, Aeolian Arc, Italy. J Petrol 48:2407-2430. https://doi.org/10.1093/petrology/egm066

Tuff J, Gibson SA (2007) Trace-element partitioning between garnet, clinopyroxene and Fe-rich picritic melts at 3 to $7 \mathrm{GPa}$. Contrib Mineral Petrol 153:369-387. https://doi.org/10.1007/s0041 0-006-0152-x

Ustaszewski K, Schmid SM, Fügenschuh B et al (2008) A map-view restoration of the Alpine-Carpathian-Dinaridic system for the Early Miocene. Swiss J Geosci 101:S273-S294. https://doi. org/10.1007/s00015-008-1288-7

van der Meer DG, van Hinsbergen DJJ, Spakman W (2018) Atlas of the underworld: slab remnants in the mantle, their sinking history, and a new outlook on lower mantle viscosity. Tectonophysics 723:309-448. https://doi.org/10.1016/J.TECTO.2017.10.004

Vaselli O, Downes H, Thirlwall M et al (1995) Ultramafic xenoliths in Plio-Pleistocene alkali basalts from the eastern Transylvanian Basin: depleted mantle enriched by vein metasomatism. J Petrol 36:23-53. https://doi.org/10.1093/petrology/36.1.23

von Blanckenburg F, Davies JH (1995) Slab breakoff: a model for syncollisional magmatism and tectonics in the Alps. Tectonics 14:120-131. https://doi.org/10.1029/94TC02051

Walter MJ (1998) Melting of garnet peridotite and the origin of komatiite and depleted lithosphere. J Petrol 39:29-60. https:// doi.org/10.1093/petroj/39.1.29

Workman RK, Hart SR (2005) Major and trace element composition of the depleted MORB mantle (DMM). Earth Planet Sci Lett 231:53-72. https://doi.org/10.1016/j.eps1.2004.12.005

Wortel MJR, Spakman W (2000) Subduction and slab detachment in the Mediterranean-Carpathian region. Science 290:1910-1917. https://doi.org/10.1126/science.290.5498.1910

Publisher's Note Springer Nature remains neutral with regard to jurisdictional claims in published maps and institutional affiliations. 